$$
\begin{aligned}
& \text { جامعـة المنصــورة } \\
& \text { كليــة التربية }
\end{aligned}
$$

فعالية برناهج إرشادي عقلاني انفعالي لزيادة الصلابة

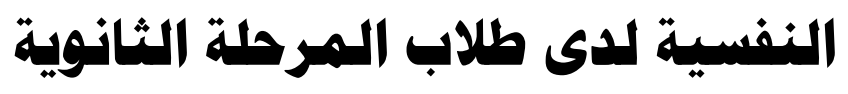
بمدينة بنغازي الايبية

$$
\begin{aligned}
& \text { إعداد } \\
& \text { علي مهدي محمد حمد الفرجاني } \\
& \text { باحث دكتوراه } \\
& \text { كلية التربية جامعة المنصورة }
\end{aligned}
$$

$$
\text { أ.د. / فؤاد حامد المو افي الثورى إنــر أ.د. / إسعاد عبد العظيم البنا (رحمها }
$$

أستاذ الصحة النفسية والتربية الخاصة المتفرغ أستاذ الصحة النفسية والتربية الخاصة المتفرغ كلية التربية - جامعة المنصورة كلية التربية - جامعة المنصورة

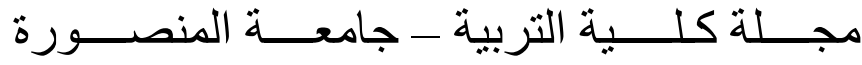

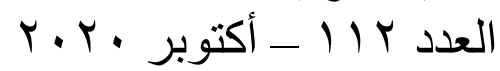




\section{فعالية برنامج إرشادي عقلاني انفعالي لزيادة الصلابة النفسية لاى طلاب المرحلة الثانوية بمدينة بنغازي الفئية الليبية}

\section{علي مهدي محمد حمد القرجاني}

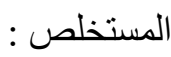

هدف هذا البحث إلى التعرف على فعالية برنامج إشادي عقلانسي انفعالي لزيادة الصلابة النفسية

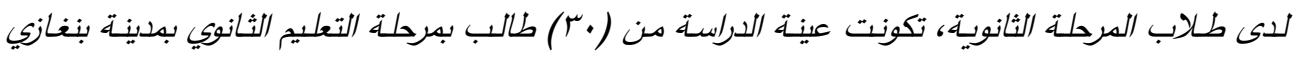

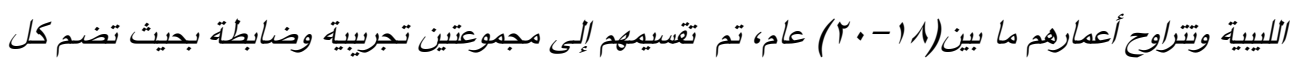

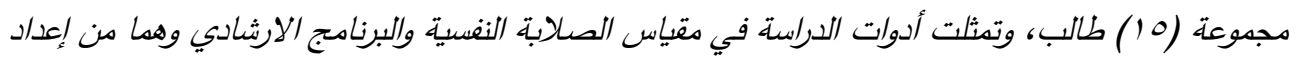
(الباحث) ومقياس الأفكار اللاعقلانية من إعداد من اعداد هوبر ولاين Hoopre, ,Layne وترجهة معتز

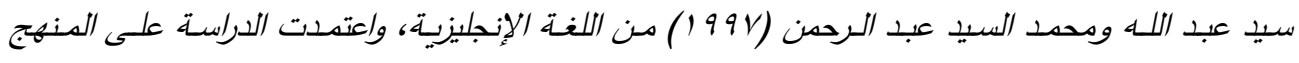

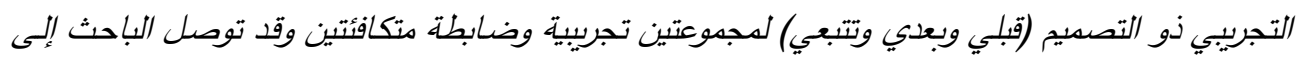
التاللي:

وجود فروق ذات دلالة إحصائية بين متوسط رتب درجات الدجموعة التجريبية في القياسين القبلي

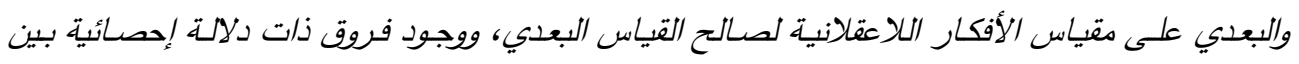

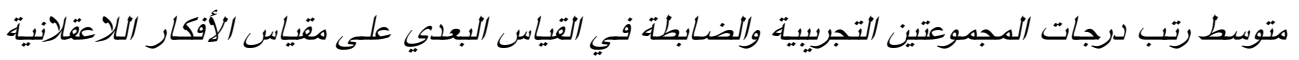

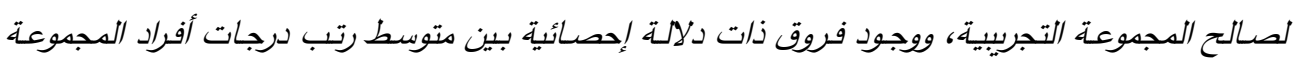

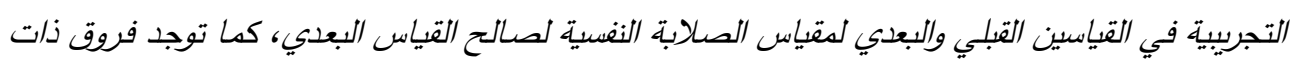

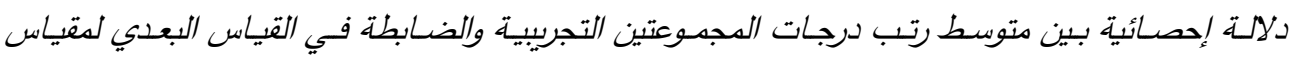

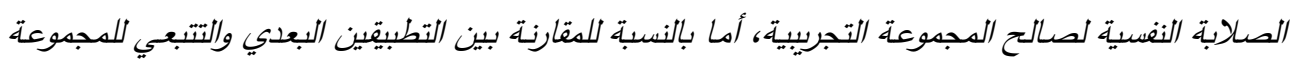

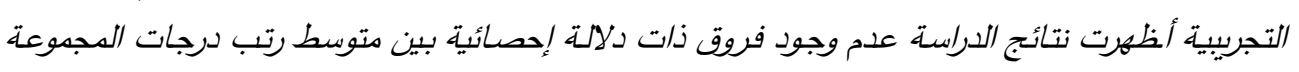

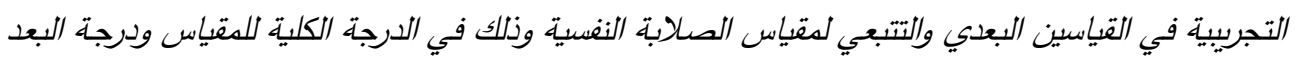

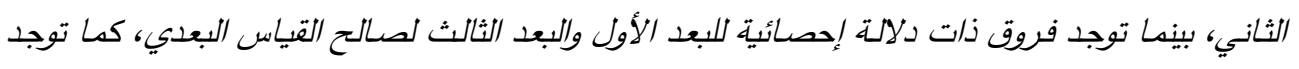

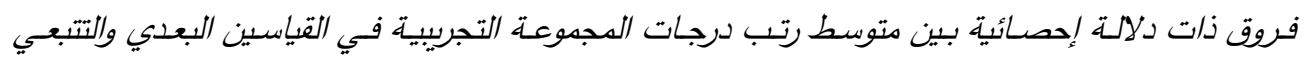

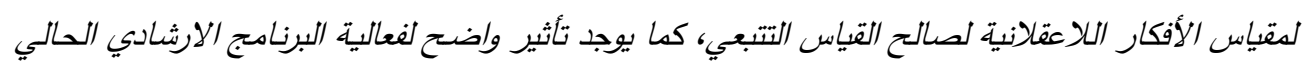
على تنمية الصلابة النفسية. الكلمات الدفتاحية: الارشاد العقلاني الانفعالي، الصلابة النفسية، طلاب المرحلة الثانوية.

\section{Abstract}

$r V \cdot \odot$ 
The aim of this research is to identify the effectiveness of a rational and emotional counseling program to increase the psychological hardiness of high school students. The study sample consisted of (30) students in the secondary education stage in Benghazi, Libya, whose ages range between (18-20) years, and they were divided into two experimental and control groups. So that each group includes (15) students, and the study tools were represented in the scale of psychological hardness and the instructional program, which were prepared by (the researcher) and the scale of irrational thoughts prepared by Huopre and Layne, and translated by Moataz Syed Abdullah and Muhammad Al-Sayed Abdel Rahman (1997) from The English language, and the study relied on the experimental approach designed (before, after and after) for two equivalent experimental and control groups, and the researcher concluded the following:

The existence of statistically significant differences between the average ranks of the experimental group scores in the pre and post measurements on the irrational ideas scale in favor of the post measurement, and the presence of statistically significant differences between the mean scores of the experimental and control groups in the post measurement on the irrational thoughts scale in favor of the experimental group, and the presence of significant differences $A$ statistic between the average ranks of the scores of the experimental group members in the pre and post measurements of the psychological hardness scale in favor of the post measurement, and there are also statistically significant differences between the average ranks of the scores of the experimental and control groups in the post measurement of the psychological hardness scale in favor of the experimental group, and as for the comparison between the post and the following applications of the group Experimental The results of the study showed that there were no statistically significant differences between the average ranks of the experimental group scores in the post and tracer measures of the psychological hardness scale in the total score of the scale and the degree of the second dimension, while there were statistically significant differences for the first and third dimensions in favor of the dimensional measurement, and there are also differences of interest. Statistical significance between the mean scores of the trial group There is a clear effect on the effectiveness of the current indicative program on the development of psychological toughness.

Key words: rational emotional counseling, psychological hardiness, high school students. 
حض الله تعالى على التنكيروأعمال العقل في قوله تعالى "قل هل يستوي الأعمى والبصير

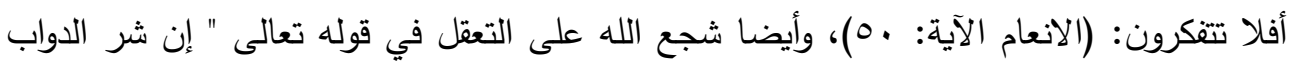

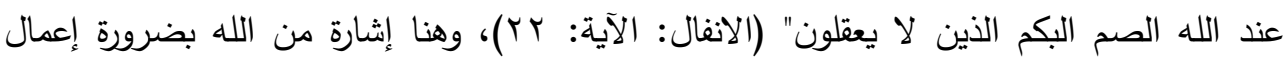

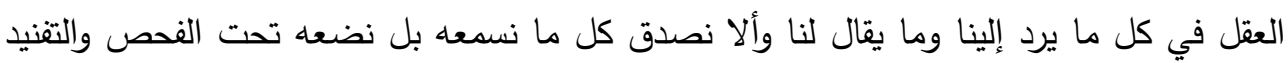
لكي نختار ونتبع أحسنه ونترك ما دون ذلك من كلام أو فكر منحرف إو لاو لاعقلاني.

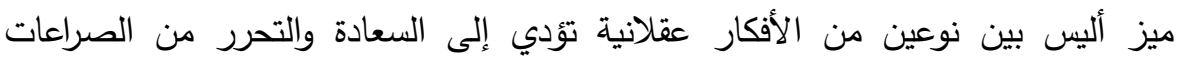
النفسية، وتساعد الثخص على تحقيق أهدافه، والأخرى لا عقلانية، غير منطقية وغير توانير واقعية

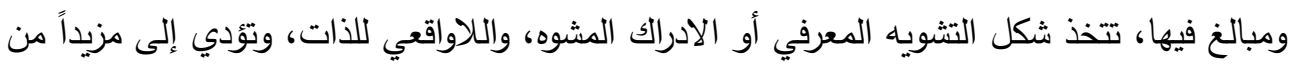

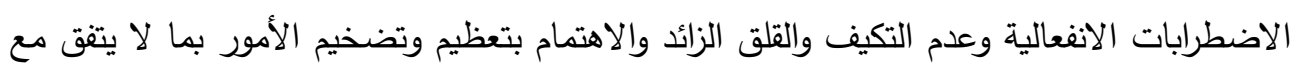

$$
\text { إمكانات لفرد الفعلية. (هشام إبراهيم عبد الله، م ... ب). }
$$

الأفكار اللاعقلانية أفكار سلبية وغير منطقية تسبب الكثير من الالام والاضطرابات وأن الثخص الذي يتبناها يظل رهين مجموعة من الاضطرابات والامراض طيلة حياته، كما أنها تعتبر سبب في ظهور العديد من المظاهر السلوكية السلبية والمرفوضة، بالإضافة إلى ارتباطها بعدة الهابط

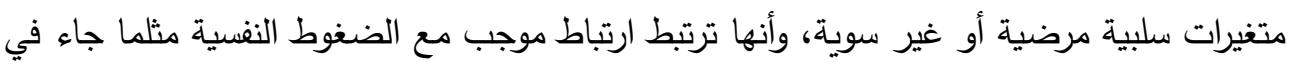

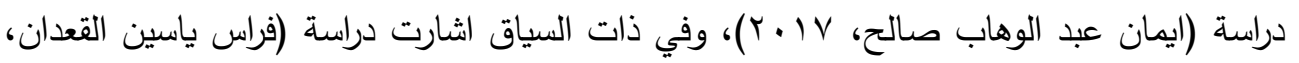

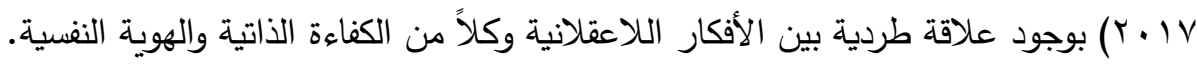
ويرجع أليس مصادر الأفكار اللاعقلانية إلى التعلم المبكر غير المنطقي حيث أن أن الفرد

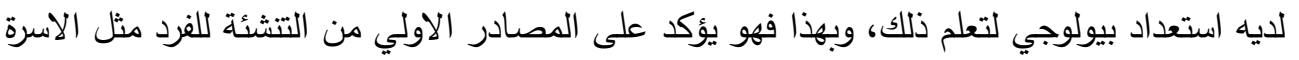

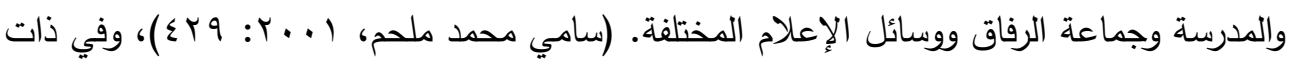

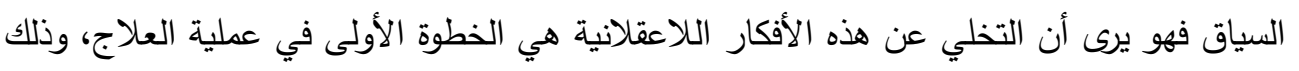
من خلال الاهتمام بالذات، والاعتماد على النفس وتحمل الإحباط والالتزام بقبول الذات وقبول

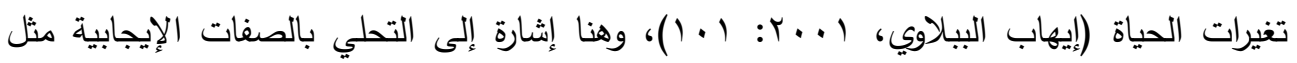

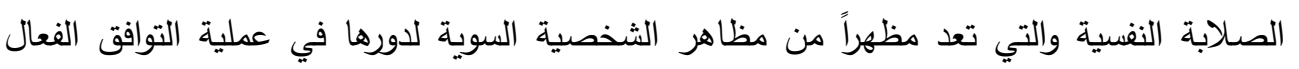

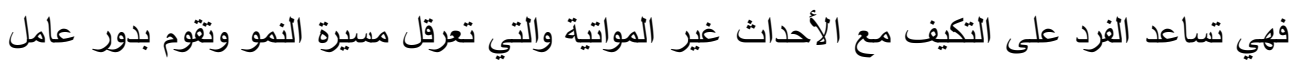

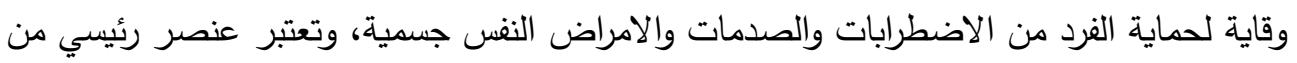

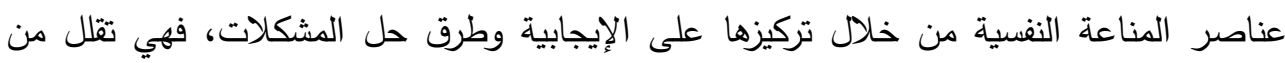
الحزن والاكتئاب والإجهاد والإحباط وتأثير الحالات السلبية (Bigalke, 2015, 17). 
والصلابة النفسية تعمل كعامل حماية من الأمراض الجسدية والاضطرابات النفسية وتجعل

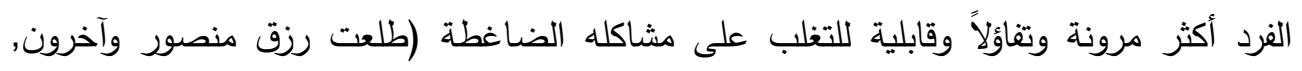
$\cdot(V \varepsilon \cdot: r \cdot) \varepsilon$

وعليه يرى الباحث أنه من الأهمية دراسة الصلابة النفسية كونها أحد أجزاء المناعة النفسية

للفرد وخاصة وقت الازمات والكوارث لان هذا الوقت يرتفع فيه مستوى الضغوط الى الحد الذيه لئه ربها يجعل الفرد يفشل في التوافق مع النفس ومع والحياة ومع الاخرين وبالتالي يكون دورنا هو تعزيز

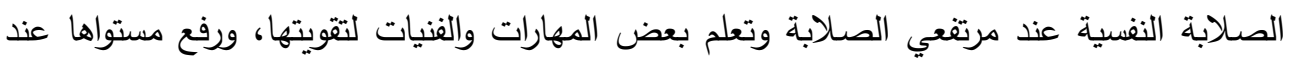
منخفضي الصلابة، لذلك من المهم التعرف على مكوناتها وطرق اكتسابها وكيفية تتميتها ودورها في تخفيف حدة الاضطرابات وخاصة لدى الثباب المراهقين من خلال الممارسات اليومية.

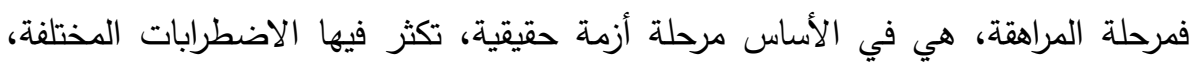

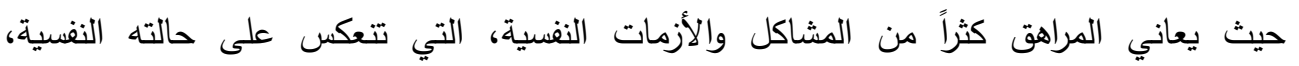
والاجتماعية والسلوكية، أثناء النمو، مما يؤثر في المرحلة التعليمية المقابلة لها وهي مرحلة التعليم

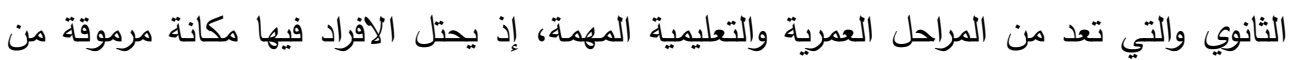
حيث الطاقة البشرية التي بصلاحها وتوجيهها وارشادها تتحقق نهضة المجتمع وتطوره، وبالمقابل

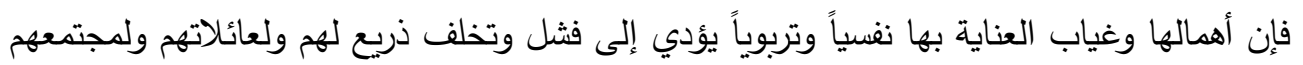

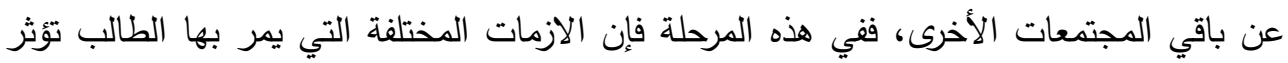

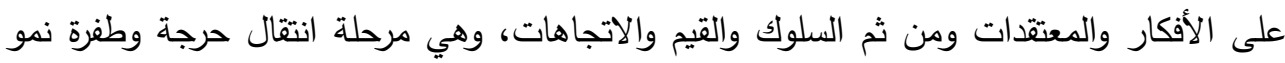
من الطفولة إلى الرشد، وتتذر خطورة تبني المعتقدات اللاعقلانية من مستقبل سيئ وغير موفق مهن لهذه الفئة فيما بعد ربما يستمر معهم طيلة الحياة وتجعل منهم افراد مرضى وعنى وعالة على انفههم واسرهم ومجتمعهم الذي يدفع تكلفة باهظة لهذا الخطأ.

مشكلة الدر اسة: من خلال كل ما سبق ذكره فقد أثار دافعية الباحث لإجراء الدراسة الحالية بهدف الكثف عن فعالية برنامج ارشادي عقلاني انفعالي لزيادة الصلابة النفسية لاى طلاب المرحلة الثانوية وعليه يمكن تحديد مشكلة الدراسة في التساؤلات التالية: 
-هل توجد فروق بين متوسط رتب درجات المجموعة التجريبية في القياسين القبلي والبعدي على

مقياس الأفكار اللاعقلانية؟

-هل توجد فروق بين متوسط رتب درجات المجموعتين التجريبية والضـابطة في القياس البعدي

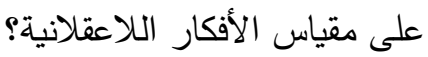

-هل توجد فروق بين متوسط رتب درجات افراد المجموعة التجريبية في القياسين القبلي والبعدي

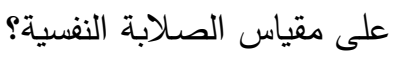

-هل توجد فروق بين متوسط رتب درجات افراد المجموعتين التجريبيـة والضـابطة في القياس

البعدي على مقياس الصلابة النفسية؟

- هل توجد فروق بين متوسط رتب درجات أفراد المجموعة التجريبية في القياسين البعدي والتتبعي

على مقياس الأفكار اللاعقلانية؟

-هل توجد فروق بين متوسط رتب درجات أفراد المجموعة التجريبية في القياسين البعدي والتتبعي

على مقياس الصلابة النفسية؟

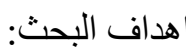

ا-تصميم برنامج ارشادي عقلاني انفعالي يتم من خلاله توظيف استراتيجيات نظريات العلاج

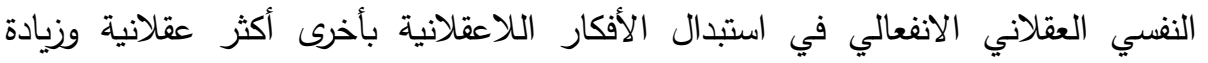
الصلابة النفسية لدى عينة من الطلاب ذوي الصلابة النفسية المنخفضة، بالمدارس الثانوية،

واختبار فعالية البرنامج في زيادة الصلابة النفسية لدى افراد العينة.

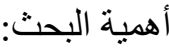

ازداد الاهتمام من جانب العلماء بالجوانب الإيجابية في الثخصية والتي تحافظ على توازن

شخصية في الفرد في مواجهة المخاطر والاضطرابات، حيث تمثل الصلابة النفسية أحد أهم العوامل

الرئيسية الإيجابية التي تقي الانسان من المخاطر والتهديدات، كما تبرز أهميتها النظرية من خلال المتغيرات التي تتاولتها فمتغير مثل الصلابة النفسية يعتبر من صميم علم النفس الإيجابي، ولها هليا تأثير كبير على صحة الفرد النفسية والجسمية ولها دور علاجي ووقائي ومكون هام من مكونات المناعة ضد مختلف الامراض الجسمية والنفسية، وكذلك تبرز أهميتها من خلال الشريحة العمرية التي تتاولتها، وهي مرحلة المراهقة، حيث أنها مرحلة فاصلة في حياة الفرد من الناحية الاجتماعية،

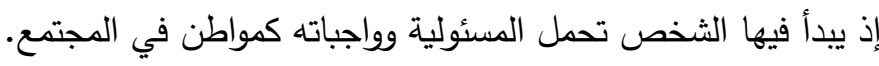


أما من الناحية التطبيقية فتعود أهميتها إلى: اثراء المكتبة بالمقاييس المعدة في هذه الدراسة

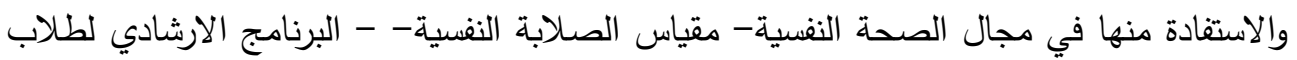

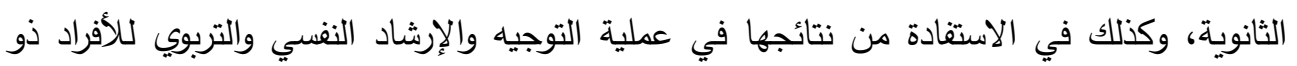
المستوى المنخفض من الصلابة النفسية حتى تتحسن حالتهم ويصبحوا اصحاء نفسيا وجسمياً. المفاهيم الإجر ائية:

\section{البرنامج الارشادي العقلاني الانفعالي:}

ويعرفه الباحث إجرائياً بأنه"مجموعة من الأنشطة والفنيات المعرفية والسلوكية والانفعالية، المخطط لها على أسس علمية مستمدة من نظرية ألبرت أليس في العلاج العقلاني الانفعالي وضعت في جلسات إرشادية منتظمة بهدف رفع مستوى الصلابة النفسية وخفض كلاً من الأفكار اللاعقلانية واضطراب ما بعد الصدمة وبناء فلسفة عقلانية أكثر سوية، لدى طلاب المرحلة الثانوية بمدينة بنغازي.

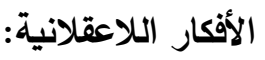

يعرف الباحث الأفكار اللاعقلانية إجرائياً " بأنها تلك الأفكار الخاطئة وغير الواقعية واللا

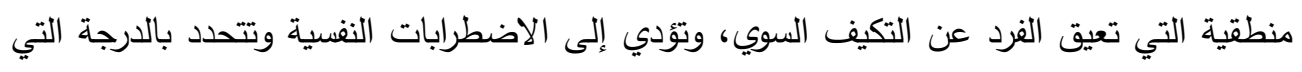
يتحصل عليها الطالب من خلال استجابته على مقياس الأفكار اللاعقلانية من اعداد هوبر ولاين وندين Hooper, Layne

\section{الصلابة النفسية:}

يعرف الباحث الصلابة النفسية إجرائياً بأنها مجموعة من المعتقدات المكتسبة عن الذات والتي تعمل على تقوية الجهاز المناعي للشخص للوقاية والتغلب على الامراض والاضطرابات واحداث الحياة الضاغطة والعمل على التوازن النفسي في ظل الصراعات الداخلية والخارجية، وتقدر بالدرجة التي يتحصل عليها الطالب على مقياس الصلابة النفسية (بأبعاده الثناثة) المعد من قبل فيل فئل الباحث.

وتحدد الدراسة الحالية ثلاثة أبعاد لمقياس الصلابة النفسية وهي:

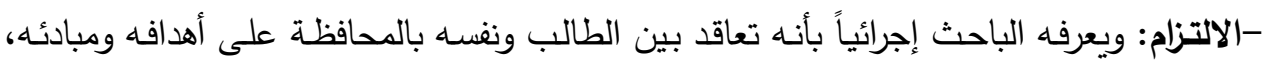

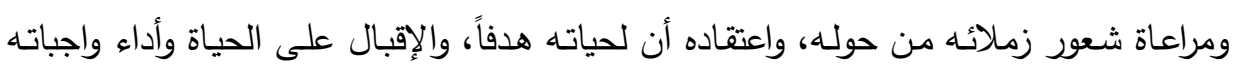
بطريقة هادفة، والمشاركة الاجتماعية الفعالة والالتزام بقوانين المجتمع، واحترام حقوق الآخرين. 
-التحكم: ويعرفه الباحث إجرائياً بأنه مدى اعتقاد الطالب بأنه بإمكانه أن يكون له تحكم فيما يلقاه

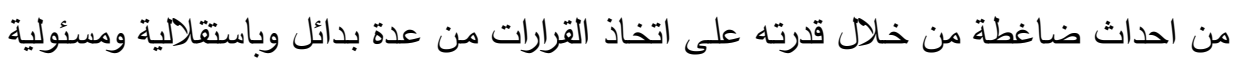
تامة مع المواجهة الفعالة وبذل الجهد الكافي في إدراك قيمة العمل والمثابرة ومسيطرا على نفسه

$$
\text { ومتحكما في أهدافه وانفعالاته وقراراته. }
$$

-التحدي: ويعرفه الباحث إجرائياً بأنها نظرة الطالب إلى ما يحدث لهاته لديه من تغيير على انه أمراً

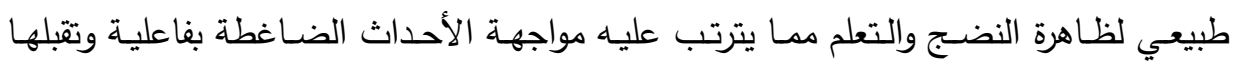
والتكيف معها والتغلب عليها والصمود أمام الاحباطات للوصول للهدف وأنها لن تثنية عن التهن تحقيق أهدافه بل تظهر مدى تحمله وقوة إرادته. إطار نظري

\section{العلاج العقلاني الانفعالي:}

يمثل العلاج العقلاني الانفعالي السلوكي نظرية في الثخصية وطريقة في العلاج النفسي،

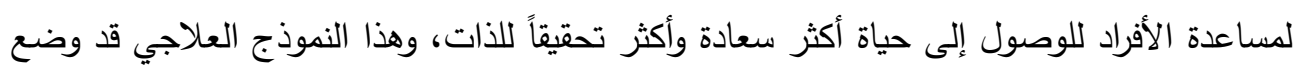

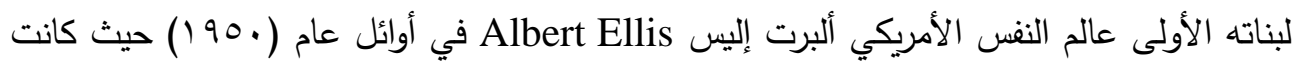

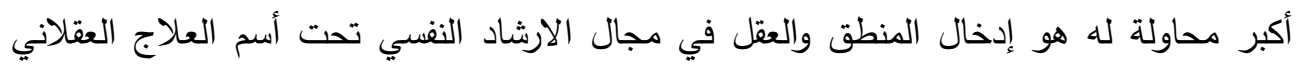

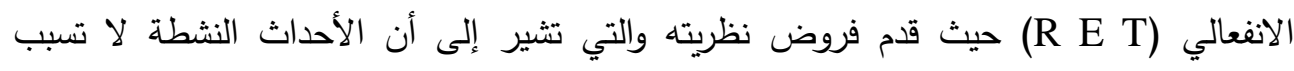

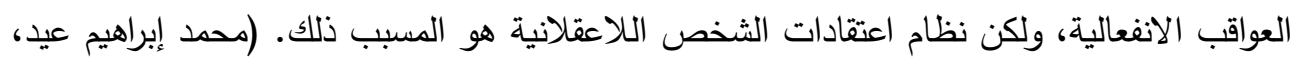

.$(r \cdot 0$

يثير إليس Ellis إلى أن جوهر العلاج العقلاني الانفعالي يتلخص في أن الأشخاص

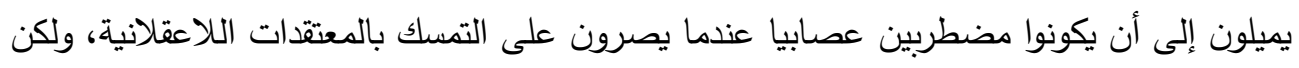
الأشخاص يعرضون أنفهم للاضطراب العصابي ليس بسبب لئبن عدم تقبل الآخرين لهم، ولكن

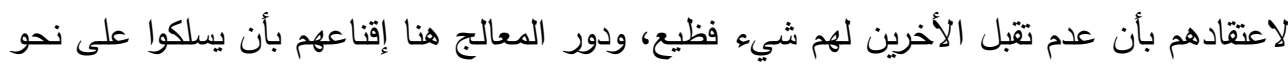

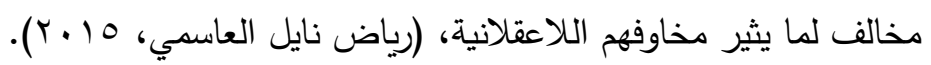
يتقسم التفكير عند أليس إلى نوعين والذي كان السبب في ظهور العلاج العقلاني الانفعالي السلوكي.

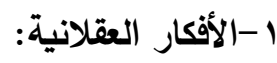

وهي الأفكار الواقعية الإيجابية ويصاحبها عواقب انفعالية ملائمة ومرغوبة، وينتج عنها

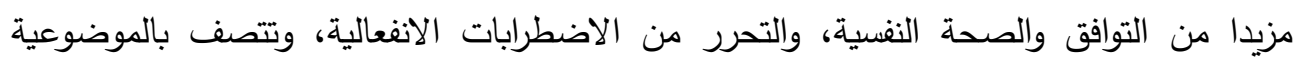


والمرونة، وتساعد على تحقيق أهداف الحياة وتقلل من الصراعات الداخلية للفرد ومن التصادم مع الأخرين.

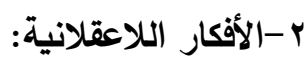

وعرفها إليس بأنها الأفكار السلبية الخاطئة غير المنطقية وغير الواقعية، والتي تتصف التهاني

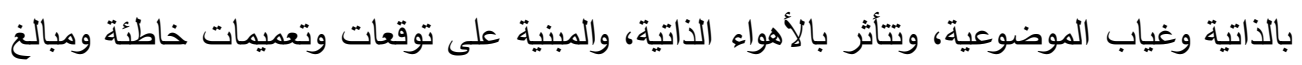
فيها ولا تتفق مع قدرات الثخص. (رنا عزيز العلي، 7 أ ب). وأشار إليس أن الأفكار اللاعقلانية تتدرج جميعها تحت ثلاث مصادر رئيسية وأن الكثير من الثنائ المشاعر السلبية الانهزامية ترتبط بفكرة أو أكثر من هذه المصادر الثثلاثة وهي، أفكار تتعلق بالذات

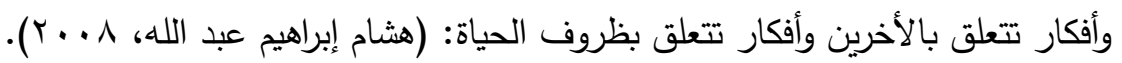
وفي ضوء ذلك حدد إليس إحدى عشرة فكرة لاعقلانية، حيث أنه أعتمد كلمة فكرة أو اعتقاد

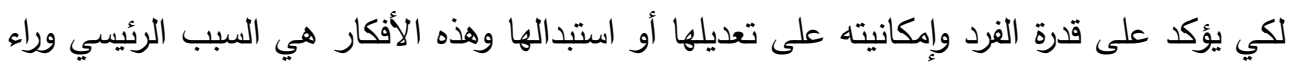
معظم الاضطرابات النفسية وهي أفكار لاحظ أليس انتثارها ووجودها في المجتمع الأمريكي بثكل متطرف ومبالغ فيه ولكنه لا يستبعد انتثارها بين الثقافات الأخرى وهي كالتالي:

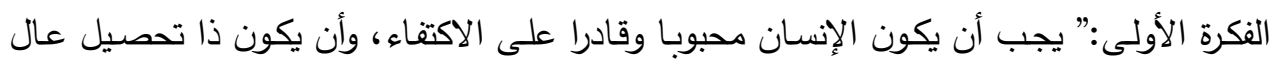
حتى يثعر بقيمته". الفكرة الثانية:" يجب أن يكون الفرد على درجه كبيره من الكفاءة والمنافسة والانجاز حتى يمكن

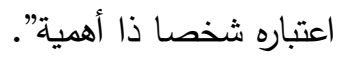
الفكرة الثالثة:" بعض الناس يتصفون بالثر والوضـاعة والجبن ولذلك فهم يستحقون أن يوجه لهم اللوم والعقاب"

الفكرة الرابعة: انه لمن النكبات المؤلمة أن تسير الأمور على غير ما يريده المرء لها"

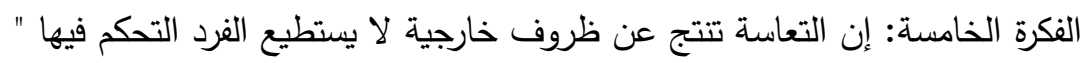
الفكرة السادسة:” إن الاشياء الخطرة تعتبر سببا للانشغال البالغ ويجب أن يكون الفرد دائم التوقع لفئع الفكرة السـابعة:" انـه مـن السـهل أن نتفـادى بعض الصـعوبات والمسئوليات الثخصـية عـن أن نواجها" الفكرة الثامنة:" ينبغي على الفرد أن يكون مستندا على آخرين وان يكون هناك شخص أقوى منهـ يستند عليه" 
الفكرة التاسعة: إن الخبرات والأحداث المتصلة بالماضـي هي المحددات الأساسية للسلوك في

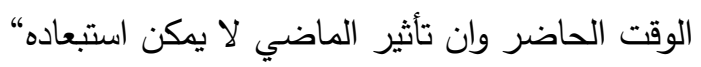

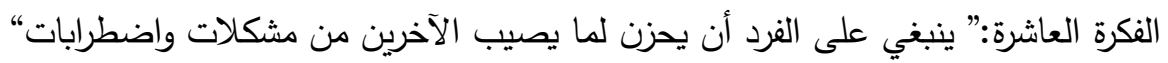

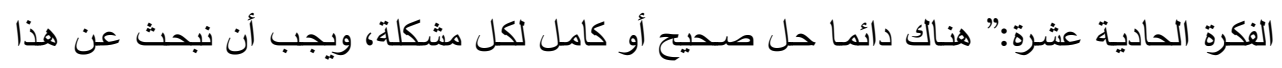

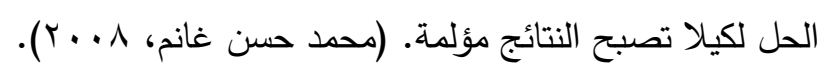

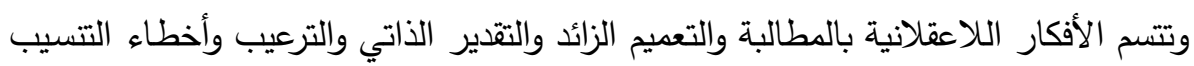

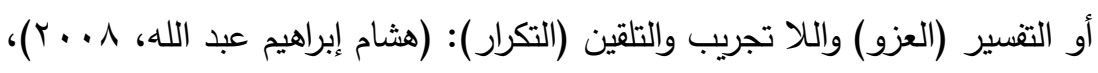

أهداف الإرشاد العقلاني الانفعالي:

إن الهدف الرئيسي للعملية الارشادية في نظرية العلاج العقلاني الانفعالي هو مناهضة

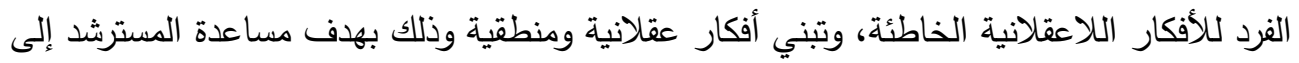

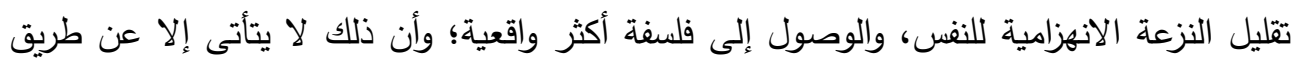

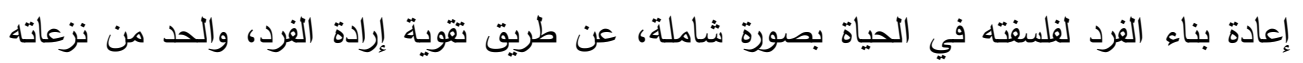

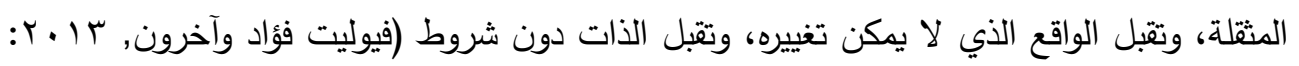

وفي سياق متصل فقد وضع أليس وبرنارد 1910 عدداً من الأهداف الخاصة بالعلاج

العقلاني الانفعالي السلوكي، والتي يعتبرونها من أهم معايير الصحة النفسية للفرد وهي: الاهني الاتصام

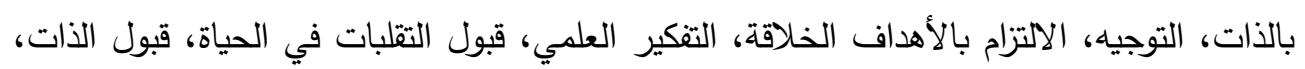

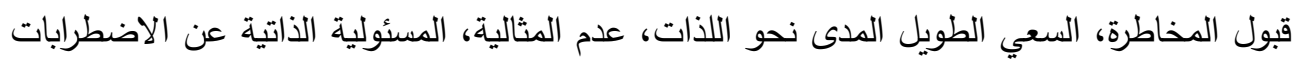

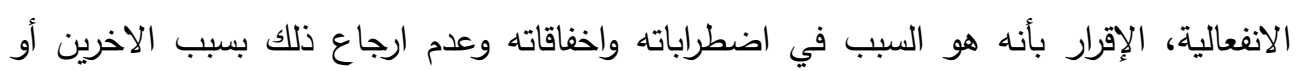

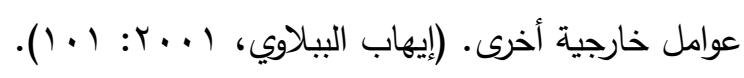

فنيات العلاج العقلاني الانفعالي:

يستخدم القائمون على الإرشاد العقلاني الانفعالي العديد من الفنيات التي تعينهم على تتفيذ البرامج، وهذه الفنيات تتمثل في فنيات سلوكية تساعد على تعديل سلوك المسترشد، وفنيات انفعالية

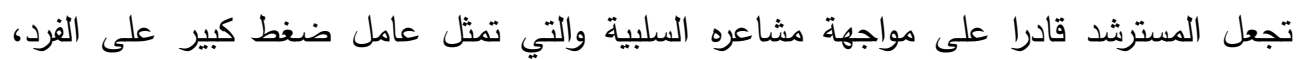

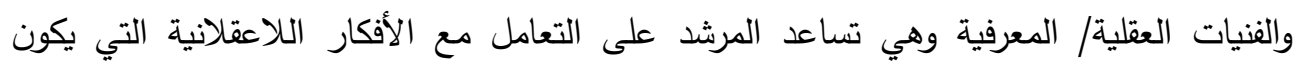

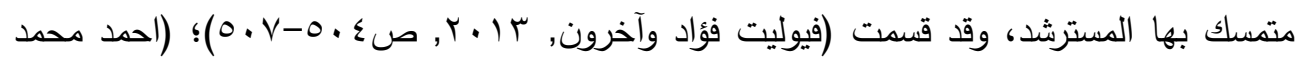

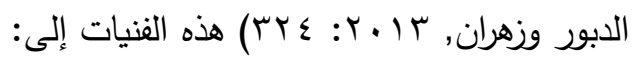




\section{1-تعلم نموذج ABCDE:}

من أهم فنيات العلاج العقلاني الانفعالي السلوكي هو تعليم المسترشد منذ بداية الجلسات

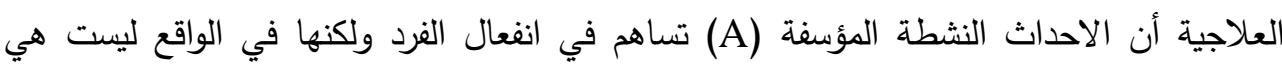

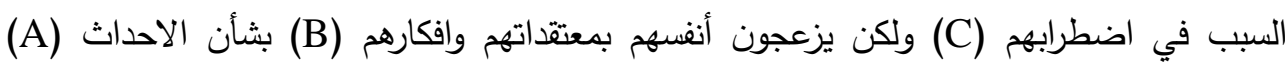
لذلك عليهم أن يعرفوا الفرق الثاسع بين المعتقدات العقلانية (RB) والمعتقدات اللاعقلانية (IB) وأن يعرفوا أن هذا الأخير هو سبب اضطرابهم، وأن يتعلموا كيف يناقثوا ويدحضوا (D) هذهات (D) المعتقدات اللاعقلانية (IB) حتى يصلوا إلى فلسفة وسلوكيات جديدة وفعالة (E)، ويمكن يوضح ولانح هذه العلاقة وشرح رموزها بشيء من التقصيل في الجدول (1) التالي: جدول ( (1) العلاقة بين مكونات نموذج اليس (ABCDE)

\begin{tabular}{|c|c|c|c|c|}
\hline & & & Activity or Action & الحدث المنشط \\
\hline Irrational Belives & المعتقدات اللاعقلانية & $\mathrm{IB}$ & \multirow[t]{2}{*}{ Belives } & \multirow[t]{2}{*}{ المتقددات } \\
\hline Rational Belives & المعتقدات العقلانية & RB & & \\
\hline Irrational Consequences & النتائج اللاعقلانية & IC & \multirow[t]{2}{*}{ Consequences } & \multirow[t]{2}{*}{ النتائج } \\
\hline Rational Consequences & النتائج العقلانية & $\mathrm{RC}$ & & \\
\hline & & & Disputing & الدحض والتقنيد \\
\hline Cognitive Effect & التأثير المعرفي & $\overline{\mathrm{CE}}$ & \multirow[t]{2}{*}{ Effect } & \multirow[t]{2}{*}{ الأثر أو التأثير } \\
\hline Behaviour Effect & التأثير السلوكي & $\overline{\mathrm{BE}}$ & & \\
\hline
\end{tabular}

وقد قسم أليس النموذج السابق إلى قسمين: القسم الأول: المرضي والذي يضم (A-IB-IC) والذي من خلاله يتضح الاضطراب إلى الانفعالي او السلوك الانهزامي. القسم الثاني: العلاجي والذي يضم (A - RB - IC - D - CE - BE) والذي يتم من خلاله تفنيد المعتقدات اللاعقلانية للوصول إلى التأثير المعرفي السلوكي، والاتجاه لحل مشاكله

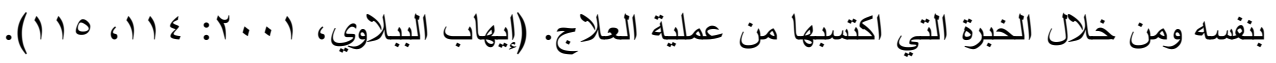
ب -فنيات معرفية: وهي التي تساعد العميل على تغيير أفكاره اللاعقلانية، واتجاهاته، وفلسفته غير المنطقية إلى أفكار واتجاهات عقلانية جديدة، وتبني فلسفة واضحة في الحياة تقوم على تعلى تعلى

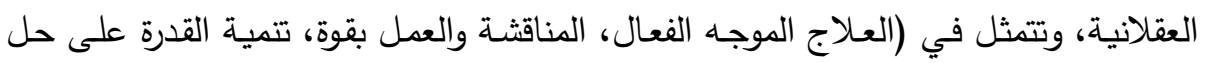
المشكلات، الدحض والإقناع). 
r-فنيـات انفعاليـة: وهي التي تتعرض لمشـاعر العميل وأحاسيسـه وردود أفعالـه تجـاه المواقف

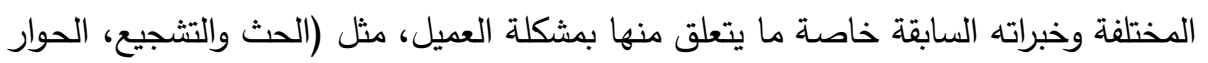

$$
\text { الذاتي، المرح، التتفيس الانفعالي، تبسيط أثر الإهانة). }
$$

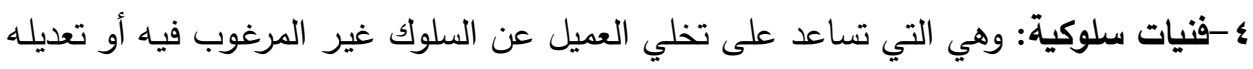

وتغييره إلى سلوك مرغوب فيه، وتدعيم هذا السلوك المرغوب ومن هذه الفنيات (التقليد ولعب العبل

$$
\text { أشكال العلاج العقلاني الانفعالي السلوكي: الاسترخاء). }
$$

يثير أليس إلى أن العلاج العقلاني الانفعالي يستخدم طرقاً متتوعة منها: العلاج الفردي،

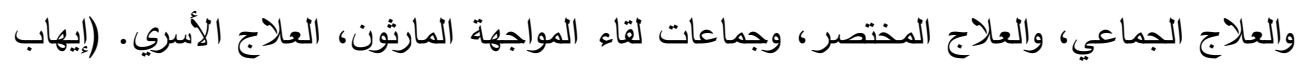

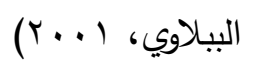

$$
\text { استخدامات العلاج العقلاني الانفعالي: الباتي: }
$$

ويشيرمعتز أن العلاج العقلاني الانفعالي يستخدم في مجالات متعددة منها على سبيل المثال

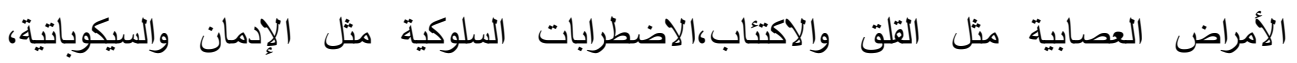
المشكلات الاجتماعية مثل المشكلات الزوجية، والمشكلات الأسرية، ومشكلات الثباب (معتز

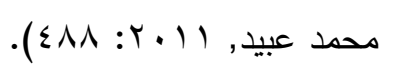

\section{الإرشاد العقلاني الانفعالي والصلابة النفسية:}

لقد تم إجراء العديد من الدراسات على تأثير الإرشاد العقلاني على الصلانلابة النفسية، وأكدت

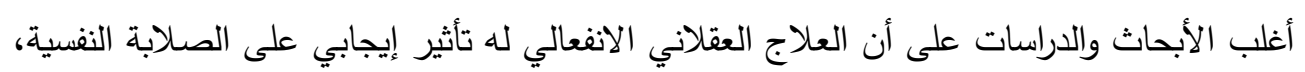

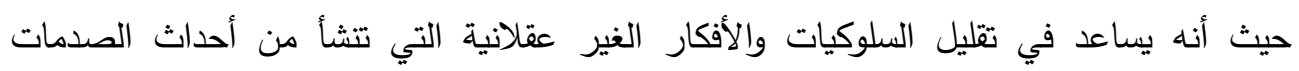
المختلفة، وقد كان هناك اختلافات وتغيرات في طريقة التفكير قبل تطبيق العلاج وبعده لدى الأفراد الذين تم تطبيق العلاج عليهه، وقد انخفضت هذه السلوكيات الغير عقلانية بشكل كبير في نهاية العلاج. 42-43) (Whatley, 2015, 42).

\section{مفهوم الصلابة النفسية:}

اقترحت كوبازا مفهوم "الصلابة النفية" في جامعة شيكاغو سنة 9 19 ، وأصبح موضع

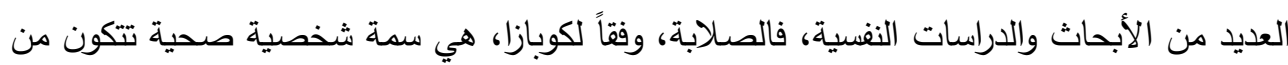

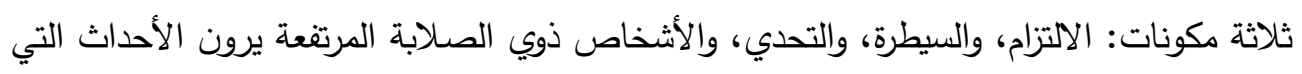

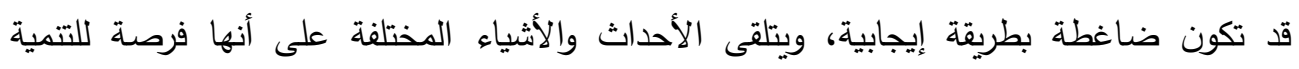


والتطوير، ويتم الآن اعتبار الصلابة على أنها أحد أشهر المتغيرات التي تتوسط التأثيرات السلبية

للأحداث الضاغطة على الصحة الجسدية والنفسية للناس (Wong, 2011, 294 \& Zhang). عرفت كوبازا (Kobassa,1979) الصلابة النفسية بأنها مجموعة من السمات الثخصية

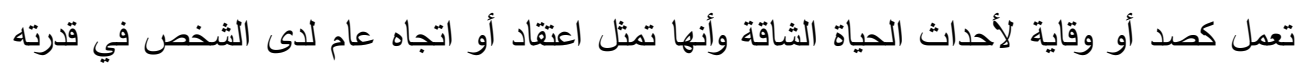

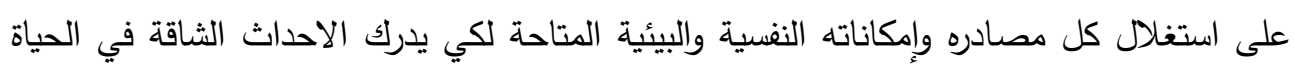
إدراكاً غير مشوهاً ويقوم بتفسيرها بمنطقية وموضوعية بالإضافة إلى التعايش معها بإيجابية وتتكون من ثلاث أبعاد رئيسية وهي الالتزام والتحكم والتحدي.

\section{- نظرية كوبازا في الصلابة النفسية (Kobassa, 9 - 9 ( )):}

يشير نموذج كوبازا الأول في الصلابة النفسية إلى وجود علاقة مباشرة بين إدرالك الضغوط الضانه

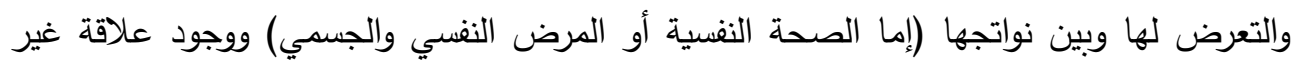
مباشرة بين إدراك الضغوط والتعرض لها وبين نواتجها حيث أن المتغيرات الوسيطة من نظر كوبازا تؤثر في إدراك الضغوط وفي نواتج الضغوط، وعلى هذا الأساس بدأت كوبازا تركز على المتغيرات

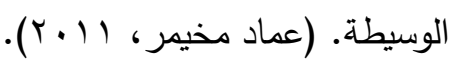

- أهمية الصلابة النفسية:

نالت الصلابة النفسية اهتمام الكثير من الباحثين أمثال: Puccetti 1983, \& Kobasa) Davidottir 2004, Farber and ,et al.200, Lambert, et al., 2003, Wiebe 199, Kobasa1979). وغيرهم من الباحثين مما يدل على مدى أهميتها، فالصلابة النفسية مركب مهم

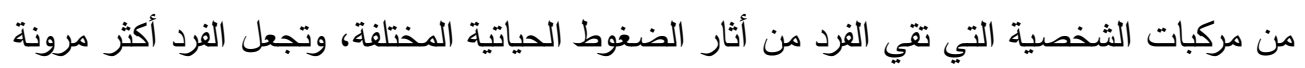

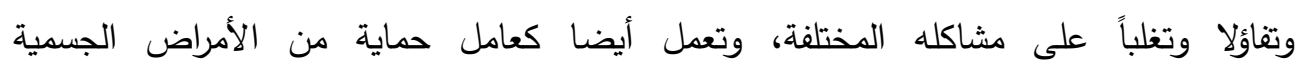
والاضطرابات النفسية، وقد لخصت كوبازا أهمية الصلابة النفسية في تعدل من إدراك الفرد للأحداث

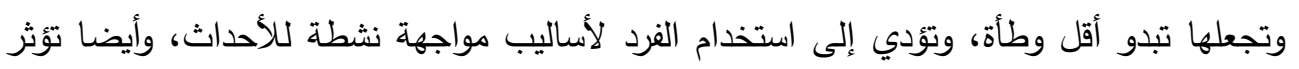

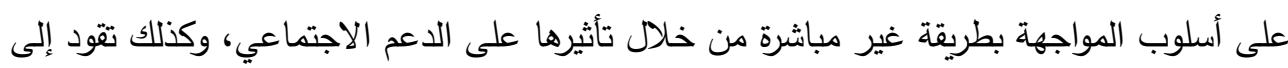
التغيير في الممارسات الصحية مثل اتباع نظام غذائي صحي وممارسة الرياضة وهذا طبعا يقلل

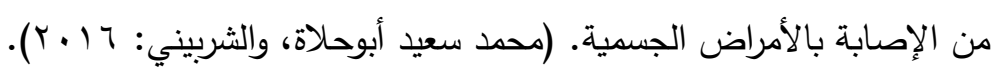
أبعاد الصلابة النفسية (مكونات الصلابة النفسية): اشارت كوبازا أن الصلابة النفسية تتكون من مركب ثلاثي الأبعاد، هي الالتزام، التحكم، دابهات

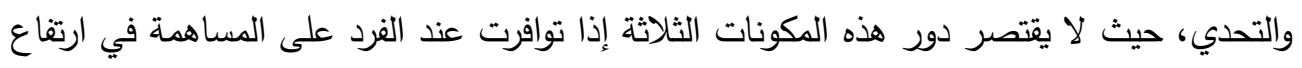




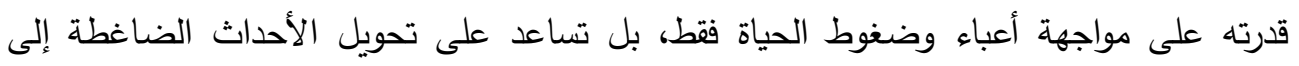

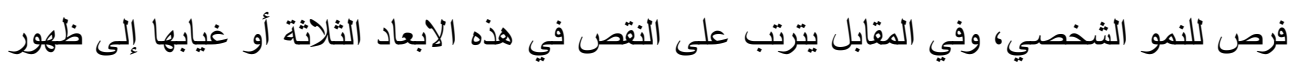
الأمراض الاضطرابات وعدم التوافق. (Kobasa,1979,pp,3-4).

\section{- خصائص الصلابة النفسية:}

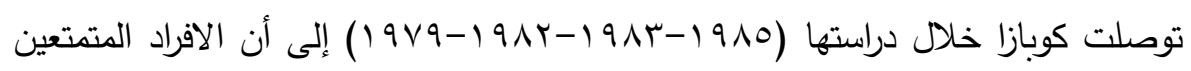
بالصلابة النفسية يتميزون بعدة خصائص منها، القدرة على الصمود والمقاومة، ولديهج أنجاز

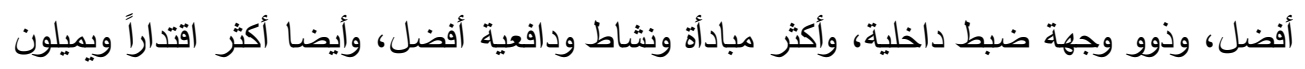

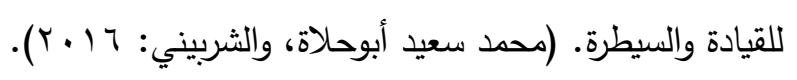
در اسات سابقة:

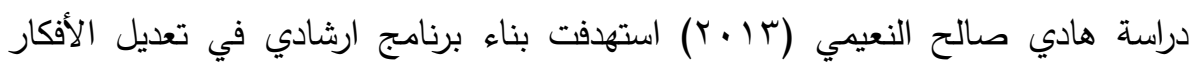

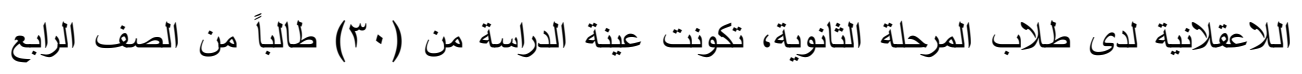

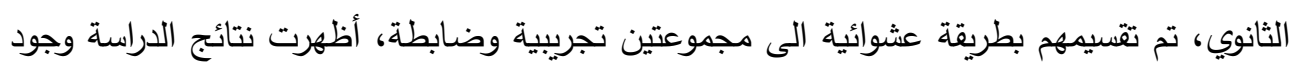

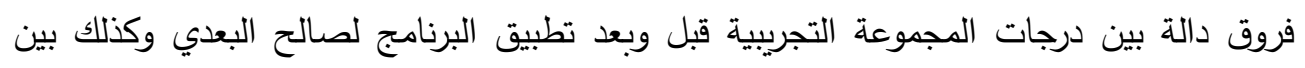
درجات المجموعتين التجريبية والضابطة بعد تطبيق البرنامج على مقياس الأفكار اللاعقلانية لصالح التجريبية، ولا توجد فروق بين التطبيقين البعدي والتتبعي للمجموعة التجريبية.

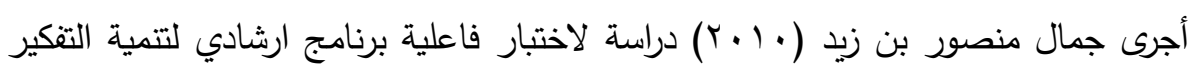

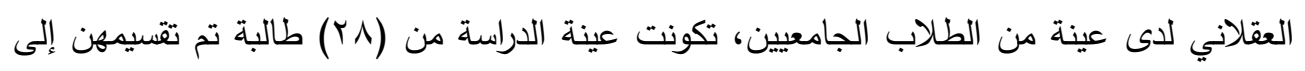
مجموعتين بالتساوي تجريبية وضابطة من الفرقة الأولى والرابعة بكلية اللغة العربية بالجامعة لكابها الأسمرية بزليتن في ليبيا، أظهرت نتائج الدراسة فعالية البرنامج الارشادي في في تلمية التئية التفكير العقلاني

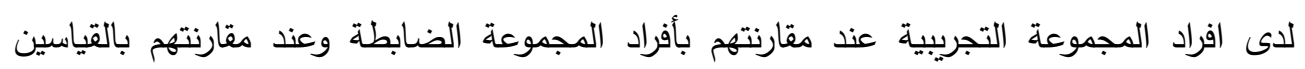
القبلي والبعدي.

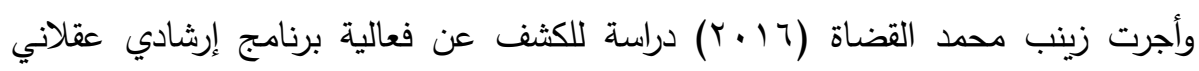

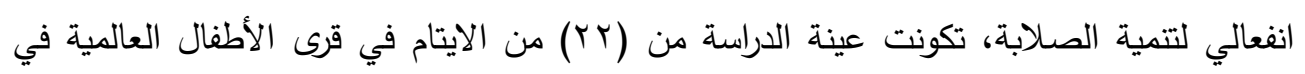
عمر (ع (1-7 (1) عام وتم تقسيمهم لمجموعتين ضابطة وتجريبية بالتساوي، واسفرت نتائج الدراسة

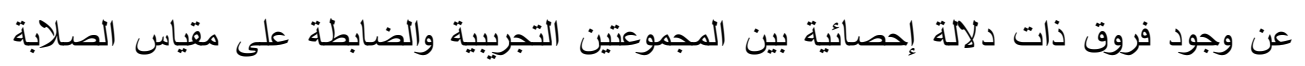
النفسية في القياس البعدي لصالح المجموعة التجريبية، كما بينت أيضا عدم وجود فروق ذات ذات دلين دلاله إحصائية بين القياسين البعدي والتتبعي للمجموعة التجريبية على مقياس الصلابة النفسية. 


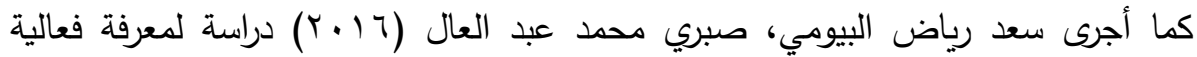

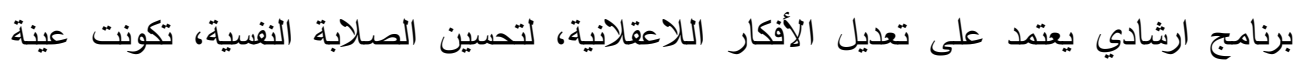
الدراسة من (•r) طالب من طلاب كلية التربية جامعة الطائف قسمت على مجموعتين تجريبية

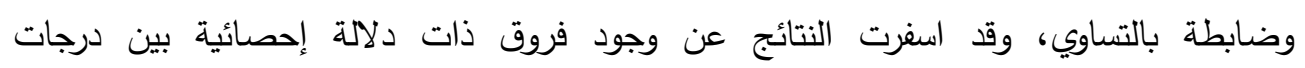

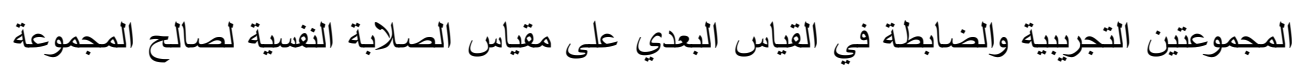

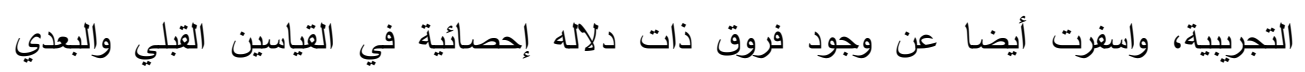

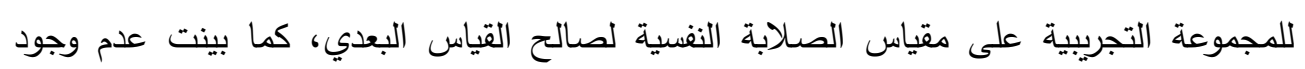

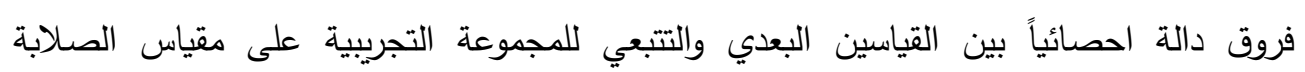
النفية.

كما هدفت دراسة عبد الله بن عبد العزيز المناحي (10 ب ب)، إلى تصميم برنامج إرشادي لتتمية الصلابة النفسية لدى المكتبئين في ضوء نظرية العلاج المعرفي السلوكي، تكونت عينة الدراسة من (7 (1) طالباً من جامعة الملك سعود بالرياض قسموا بالتساوي لمجموعتين تجريبية وضابطة، واسفرت نتائج الدراسة عن وجود فروق دالة احصائياً بين القياسين القبلي والبعدي بالئي للمجموعة التجريبية على مقياسي الصلابة النفسية والاكتئاب لصالح القياس البعدي، كما أظهرت

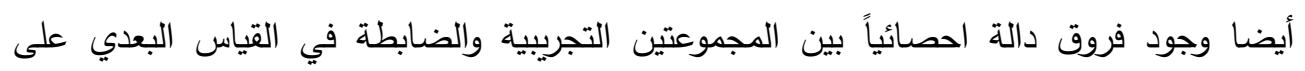
مقياسي الصلابة النفسية والاكتئاب لصالح المجموعة التجريبية.

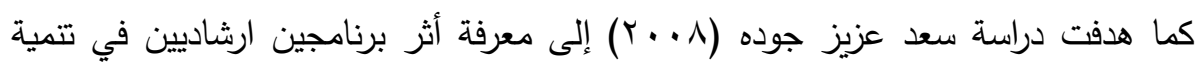

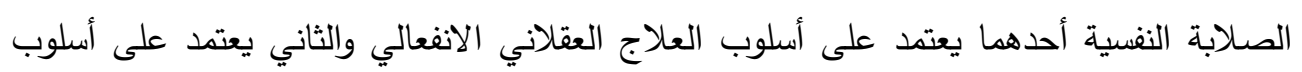

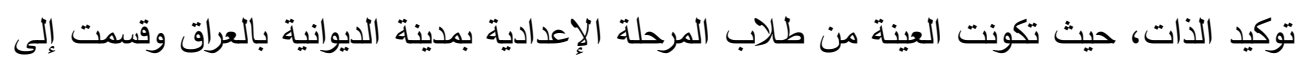
ثلاث مجموعات مجموعتان تجريبيتان وأخرى ضابطة بواقع (Y) ( ) طالب لكل مجموعة، التجريبيتان

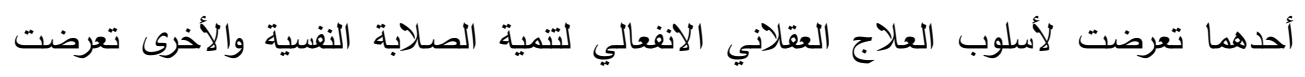

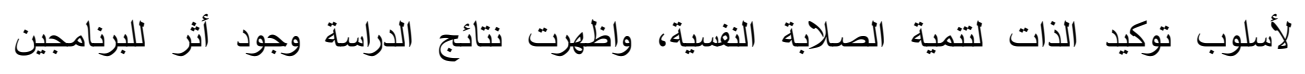
الارشاديين في تتمية الصلابة النفسية، كما أظهرت أيضا وجود فروق دالة بين المجموعتين التجريبيتين فيما يتعلق بتتمية الصلابة النفسية لصالح مجموعة أسلوب توكيد الذات. فروض البحث: ا-توجد فروق ذات دلالمـة إحصـائية بين متوسط رتب درجـات افراد المجموعـة التجريبيـة في التي القياسين القبلي والبعدي على مقياس الأفكار اللاعقلانية لصالح القياس البعدي. 
ب-توجد فـروق ذات دلالــة إحصـائية بـين متوسط رتب درجـات افـراد المجمـوعتين التجريبيـة

والضابطة في القياس البعدي على مقياس الأفكار اللاعقلانية لصالح المجموعة التجريبية.

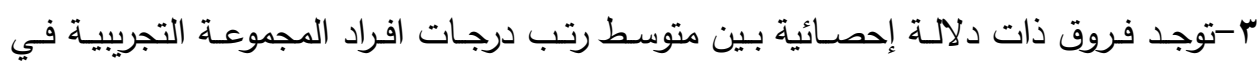
القياسين القبلي والبعدي على مقياس الصلابة النفسية لصالح القياس البعدي.

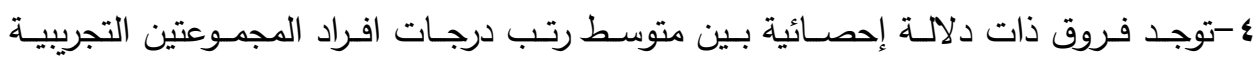

والضابطة في القياس البعدي على مقياس الصلابة النفسية لصالح المجموعة التجريبية.

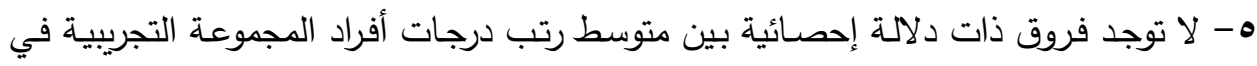
القياسين البعدي والتتبعي على مقياس الأفكار اللاعقلانية.

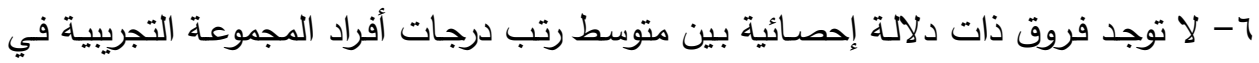
القياسين البعدي والتتبعي على مقياس الصلابة النفسية.

$$
\text { إولاً اءنهات البحث }
$$

اعتمد الباحث على المنهج التجريبي وتم استخدام التصميم ذي المجوعتين المتكافئتين،

مجموعة تجريبية وأخرى ضابطة بقياس قبلي وقياس بعدي وقياس تتبعي للمجموعة التجريبية.

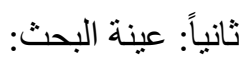

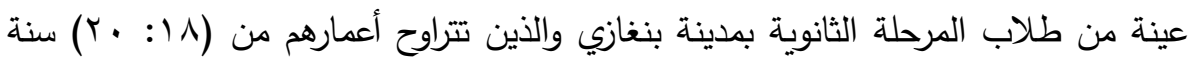
تم تطبيق مقياس الأفكار اللاعقلانية (ترجمة معتز سيد عبد الله، و99 (1)) ومقياس الصلابة النفسية من إعداد (الباحث) وتم إيجاد المتوسط الحسابي والانحراف المعياري للمتغيرات، وتم تحديد الطلاب

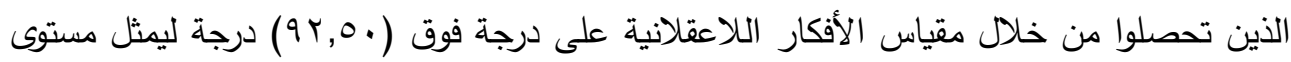

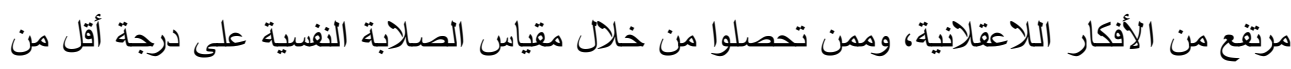

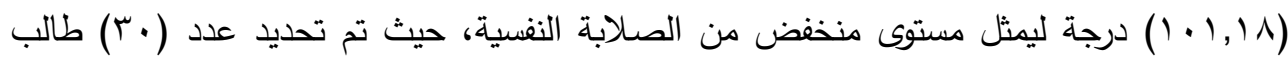
منهم وتم تقسيمهم من خلال التوزيع العشوائي إلى مجموعتين المجموعة التجريبية وعددها (10) طالب والمجموعة الضابطة وعددها (10) طالب.

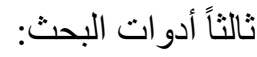
1-مقياس الأفكار اللاعقلانية (ترجمة معتز سيد عبد الله، لو 1991). r-مقياس الصلابة النفسية (إعداد البحث). r-البرنامج الارشادي العقلاني الانفعالي (إعداد الباحث).

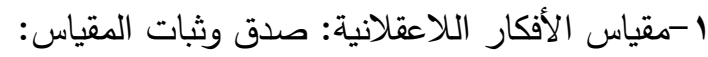


- الصدق الظاهري: تم عرض المقياس على مجموعة من المحكمين من أساتذة التربية وعلم النفس

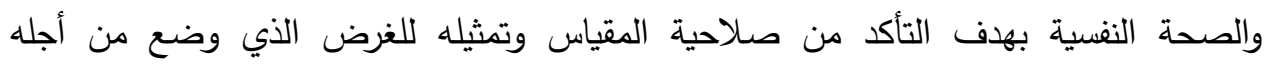
والاستفادة من ملاحظتهم وآرائهم في تعديل بعض المضردات الموجودة في المقياس.

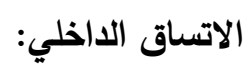

تم حساب الاتساق الداخلي لمقياس الأفكار اللاعقلانية عن طريق إيجاد معامل الارتباط بين كل مفردة من مفردات المقياس والدرجة الكلية له قبل وبعد الحذف وذلك من خلال معامل ارتباط

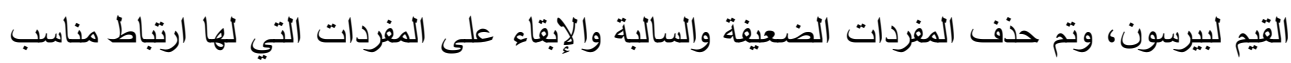

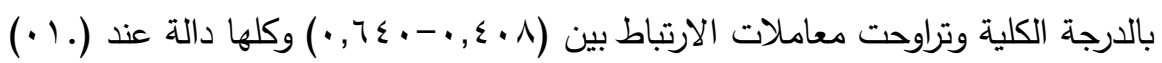

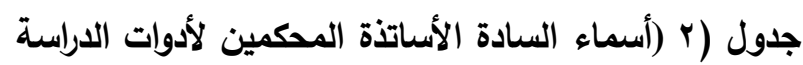

(تم ترتيب الأسماء حسب الترتيب الابجدي)

\begin{tabular}{|c|c|c|c|}
\hline جهة العمل & التخصص & 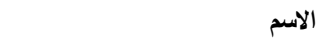 & 5 \\
\hline كلية التربية جامعة الزقازيق & التربية الخاصة & أ.د. إيمان فؤاد الكاشف & 1 \\
\hline كلية التربية جامعة الزقازيق & الصحة النفسية & أ.د. إيهاب عبد العزيز الببلاوي & r \\
\hline كلية التربية جامعة المنصورة & الصحة النفسية & أ.د. عصام محمد زيدان & r \\
\hline جامعة العرب الطبية بنغازي & الطب النفسي & أ.د. علي محمد الرويعي & $\varepsilon$ \\
\hline كلية التربية جامعة الزقازيق & الصحة النفسية & أ.د. فوقيه حسن عبد الحميد رضوان & 。 \\
\hline كلية التربية جامعة المنصورة & الصحة النفسية & أ.د. فوقيه محمد محمد راضي & 7 \\
\hline كلية التربية جامعة الزقازيق & الصحة النفسية & أ.د. محمد احمد سعفان & $\mathrm{V}$ \\
\hline كلية التربية جامعة المنصورة & الصحة النفسية & أ.د. محمود مندوه & $\wedge$ \\
\hline كلية التربية جامعة المنصورة & الصحة النفسية & د. كريم منصور عصران & 9 \\
\hline كلية التربية جامعة المنصورة & الصحة النفسية & د. محمد عيسى محمد عيسى & 1. \\
\hline
\end{tabular}

ثبات مقياس الأفكار اللاعقلانية:

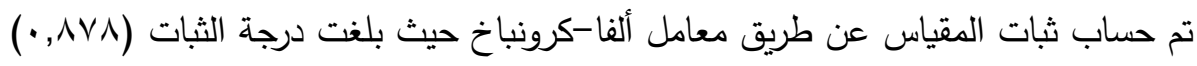

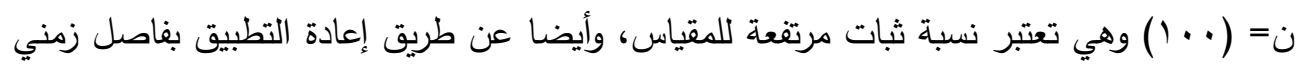
أسبوعين على عينة ن= (•) حيث بلغ معامل الارتباط بين التطبيق الأول والتطبيق الثاني $\cdot(\cdot, \vee \vee \cdot)$

-وبذلك يصبح العدد الكلي لمفردات المقياس (ץr) مفردة، والاختيار من بين بدائل خماسية. مقياس الصلابة النفسية (أعداد الباحث): 
تم تصميم المقياس في ضوء الادب التربوي والدراسات السابقة حول الصلابة النفسية حيث تم الاطلاع على عدداً من المقاييس التي تقيس الصلابة النفسية. الخصائص السيكومترية لمقياس الصلابة النفسية:

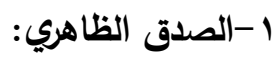

تم عرض المقياس في صورته الأولية على عشرة محكمين من أساتذة الصحة النفسية، بهدف التأكد من صلاحية المقياس وتمثيله للغرض الذي وضع من أجله والاستفادة من ملاحظتهم

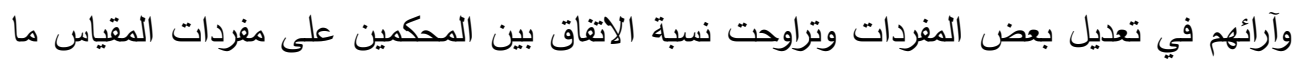

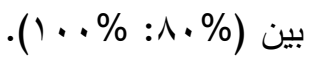

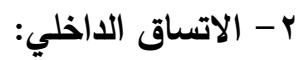

تم تطبيق المقياس على عينة مكونة من ( · . (1) طالب من طلاب المدارس الثانوية بنين،

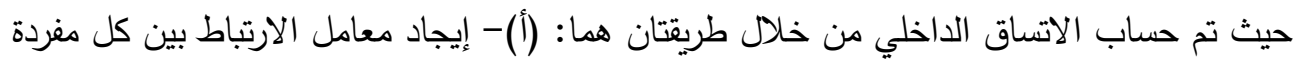

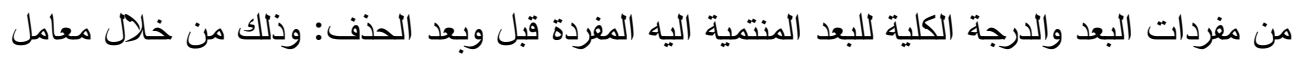
ارتباط القيم لبيرسون، وتم حذف المفردات الضعيفة والسالبة والإبقاء على المفردات التي لها ارتباط

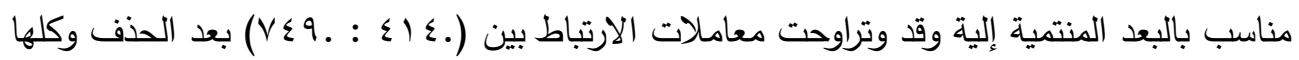
دالة عند (. (·) حيث تم حذف المفردات التي كانت ارتباطاتها ضعيفة أو سالبة ليستقر المقياس

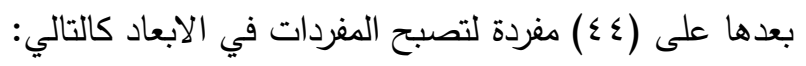

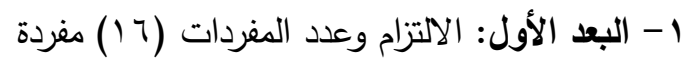

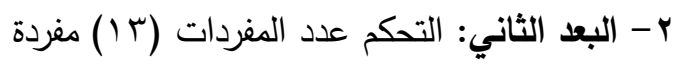

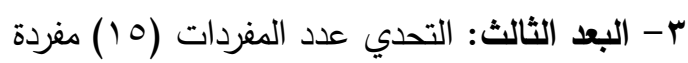

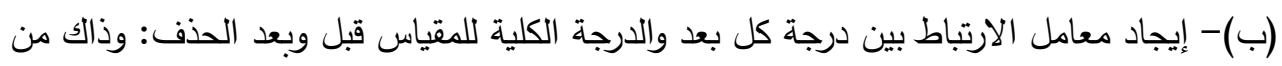

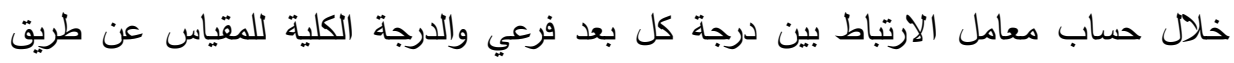

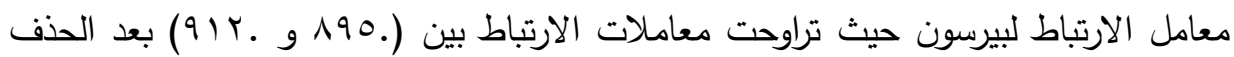

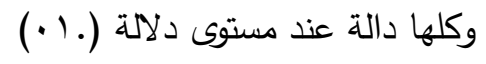

ثالثاً:الصدق التلازمي: تم استخدام مقياس الصلابة النفسية من اعداد عماد محمد مخيمر (1) (1)

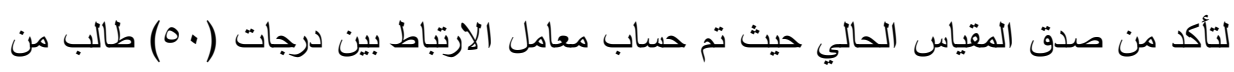
مدارس المرحلة الثانوية بمدينة بنغازي على المقياس الحالي ودرجاتهم على مقياس مخيمر 


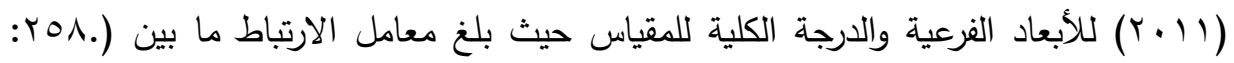

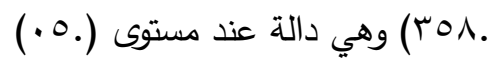

$$
\begin{aligned}
& \text { ثبات مقياس الصلابة النفسية: }
\end{aligned}
$$

تم حساب معاملات الثبات لمقياس الصلابة النفسية كالتالي: معامل الفا-كرونباخ: قام

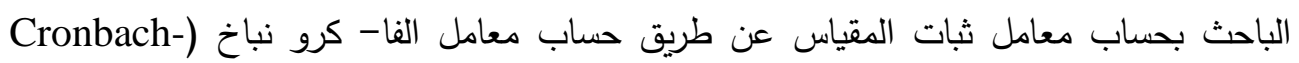
(Alpha ثبات مرتفعة مما يدل على ثبات الابعاد الفرعية والدرجة الكلية للمقياس.

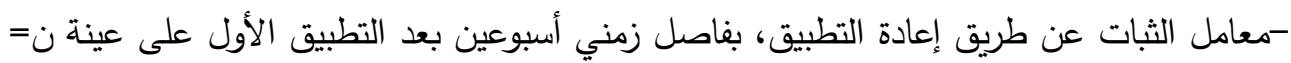

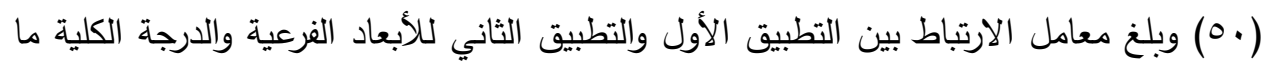

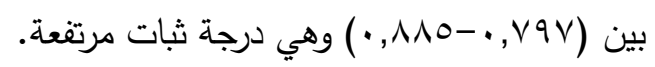

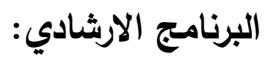

بعنوان (فعالية برنامج ارشادي عقلاني انفعالي لتتمية الصلابة النفسية لدى طلبة المرحلة

الخلفية النظرية التي يستند عليها البرنامج:

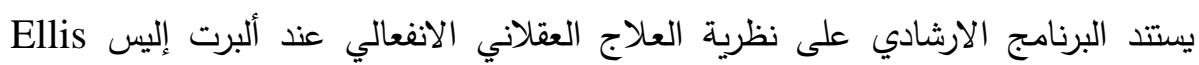

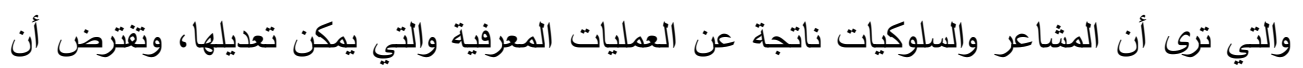

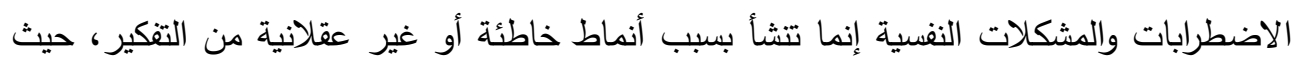
أن الاحداث النشطة لا تسبب العواقب الانفعالية والاضطراب ولكن نظام الاعتقاد الخاطئ واللاعقلاني لاى الفرد هو المسبب ذلك. (هشام إبراهيم عبد الله، م . . ب).

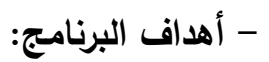
الهدف الرئيسي للبرنامج الارشادي هو رفع مستوى الصلابة النفسية، وخفض درجة الأفكار اللاعقلانية لاى مجموعة من طلاب الثانوية بمدينة بنغازي. إجراءات البرنامج ومحتواه:

يتكون البرنامج من (YV) جلسة ارشادية ومدة كل جلسة (•T) دقيقة وتطبق بواق ثلاث

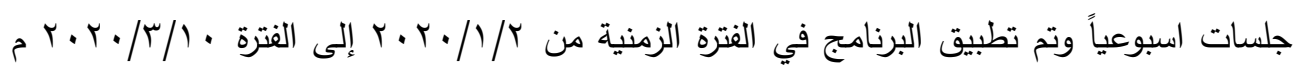
حيث شمل البرنامج ثلاث مراحل تتمثل في التالي: الأول: جلسات خاصة للتعارف ومدخل لجلسات البرنامج. 
الثاني: جلسات خاصة متعلقة بدحض وتقنيد الأفكار اللاعقلانية.

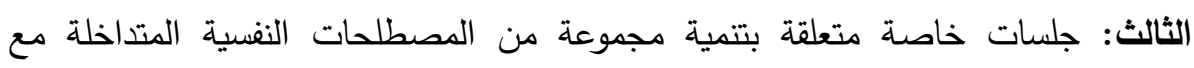
مصطلح الصلابة ولها علاقة موجبة معها بحسب ما ورد في دراسات سابقة ومن خلالها نتوقع من تتمية الصلابة لدى عينة البرنامج من خلال فنيات وأساليب نظرية العلاج العقلاني الانفعالي وهذه المصطلحات هي إحدى عشر مصطلح وهي: (تقدير الذات، الاستبصار وفاعلية الذات، ضبط

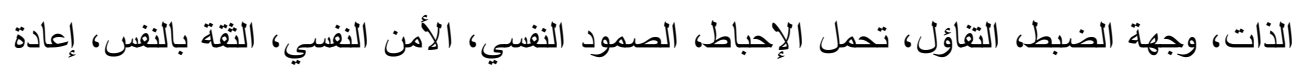
البنية المعرفية، المرونة النفسية). الأسلوب المستخدم في البرنامج: تم استخدام أسلوب الارشاد الجماعي أثناء تطبيق جلسات البرنامج، تم اختيار عدة فنيات

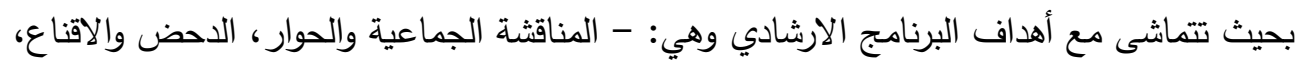

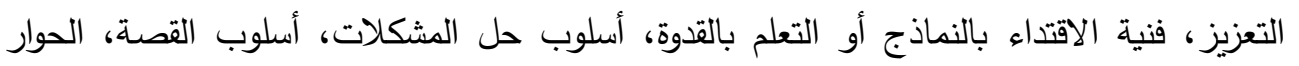
الذاتي، فنيات التخيل العقلاني الانفعالي، تبسيط أثر الإهانة، التكليفات المنزلية. نتائج البحث وتفسير ها: نتائج الفرض الأول: ينص على (توجد فروق ذات دلالمة إحصائية بين متوسط رتب درجات

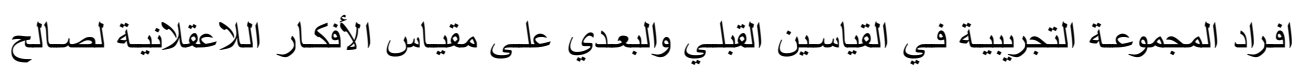
القياس البعدي. للتحقـق مـن هــا الفـرض تـم اسـتخدام اختبـار ويلكوكسـون اللابـارامتري لإثــارات الرتب

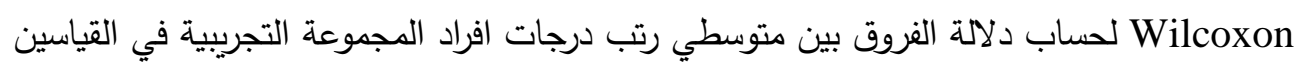

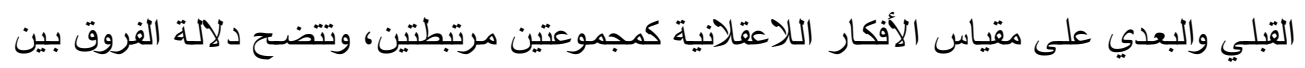
متوسطي رتب درجات المجموعة التجريبية في القياسين القبلي والبعدي من خلال الجدول التالي: جدول (r) قيم (Z) لدلالة الفروق بين متوسطي رتب درجات المجموعة التجريبية قبل وبعد تطبيق البرنامج على مقياس الأفكار اللاعقلانية.

\begin{tabular}{|c|c|c|c|c|c|c|}
\hline مستوى الدلالة & قيمة Z & مجموع الرتب & متوسط الرتب & العدد & القياس & المقياس \\
\hline \multirow[t]{2}{*}{$\cdot, \cdots 1$} & \multirow[t]{2}{*}{$-r, \varepsilon \cdot \wedge$} & 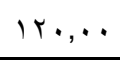 & $\wedge, \cdots$ & 10 & القبلي & \multirow[t]{2}{*}{ الأفكار اللاعقلانية } \\
\hline & & $\cdot, \cdots$ & $\cdot, \cdots$ & 10 & البعدي & \\
\hline
\end{tabular}

يتضح من جدول (r) وجود فروق ذات دلالة إحصائية بين متوسطي رتب درجات

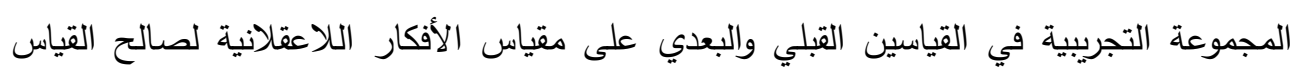




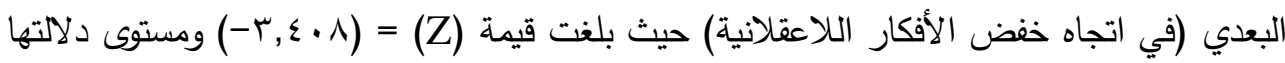
= = ( ( . , • ) مما يدل على فعالية البرنامج الإرشادي المستخدم في الدراسة الحالية. نتائج الفرض الثاني:

وينص على أنه (توجد فروق ذات دلالة إحصائية بين متوسط رتب درجات افراد المجموعتين

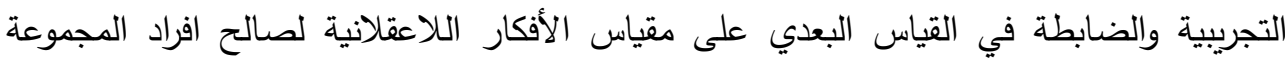
التجريبية).

Mann-Whitney ) للتحقق من هذا الفرض تم استخدام اختبار مان ويتتي اللا بارامتري (Nonparametric

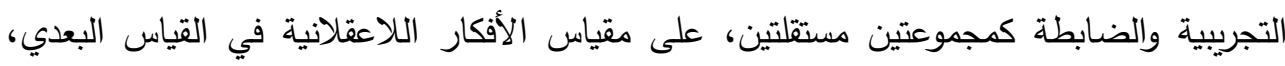

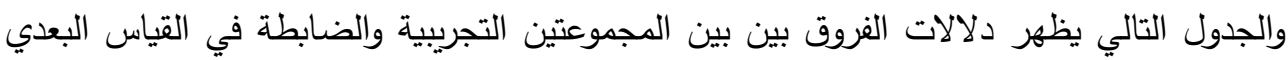

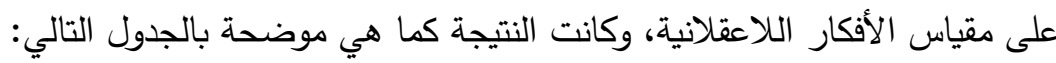
جدول (ع)

نتائج اختبار مان وتتي U للعينات المستقلة للدلالة الفروق بين متوسطات رتب درجات مجموعتي الدراسة (التجريبية والضابطة) على مقياس الأفكار اللاعقلانية في القياس البعدي

\begin{tabular}{|c|c|c|c|c|c|c|}
\hline مستوى الدلالة & $\mathrm{U}$ & مجموع الرتب & متوسط & العدد & المجموعة & المقياس \\
\hline \multirow[t]{2}{*}{$\cdot, \cdots$} & \multirow[t]{2}{*}{$r, \ldots$} & $N r, .$. & $\Lambda, r$. & 10 & تجريبية & \multirow[t]{2}{*}{ الأفكار اللاعقلانية } \\
\hline & & $r \leqslant r, \cdot$. & $r r, \Lambda$. & 10 & ضابطة & \\
\hline
\end{tabular}

يتضح من جدول (§) وجود فروق ذات دلالة إحصائية بين متوسطي رتب دربطات المجموعتين التجريبية والضابطة في القياس البعدي على مقياس الأفكار اللاعقلانية وذلك لصالح المتوسط الأقل وهو متوسط درجات افراد المجموعة التجريبية، عند مستوى دلالة إحصائية (. (...) مما يشير إلى فعالية البرنامج الارشادي المستخدم في الدراسة الحالية. تتقق هذه النتيجة مع نتائج عدد من الدراسات السابقة والتي تتاولت فعالية برامج الارشاد العقلاني الانفعالي لسلوكي في تعديل التقكير اللاعقلاني لدى عينات مختلفة ومنها دراسة جمال

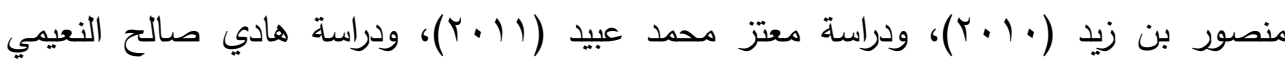

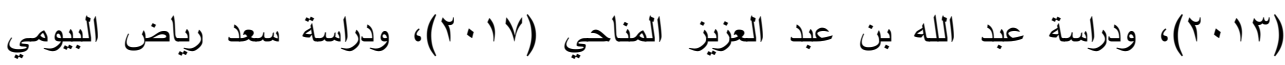
.$(r \cdot 19)$ 
وتكثف هذه النتيجة بأن الموضوعات والأساليب الفنية التي تناولتها جلسات البرنامج الارشادي قد تمكنت من دحض الأفكار اللاعقلانية لدى افراد العينة التجريبية، لذلك قد تكون الأنثطة وأساليب الحوار اتاحت الفرصة أمام الطلاب للتعبير عن معتقداتهم وآرائهم بحرية ودون

-كذلك تدريب الطلاب على كيفية استخدام نموذج أليس في العلاج العقلاني الانفعالي (ABC)

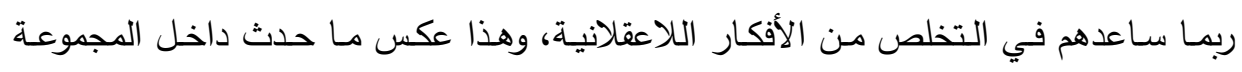

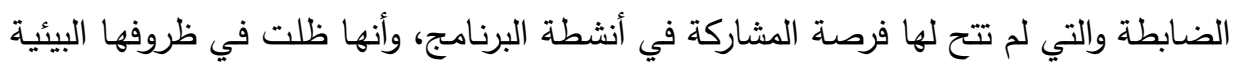

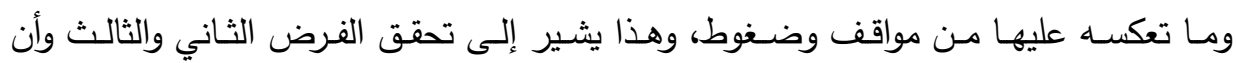

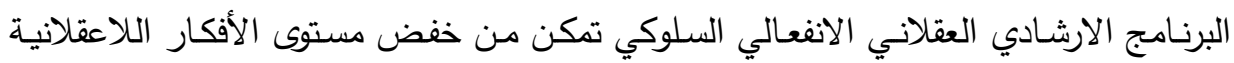
لاى المجموعة التجريبية، بعد تطبيق جلسات البرنامج. نتائج الفرض الثالث: ائ وتتص على أنه(توجد فروق ذات دلالة إحصائية بين متوسط رتب درجات افراد المجموعة التجريبية في القياسين القبلي والبعدي على مقياس الصلابة النفسية لصالح القياس البعدي).

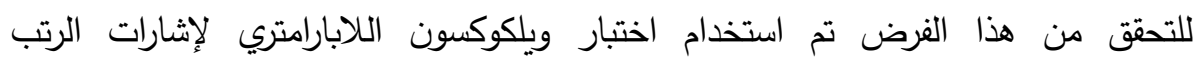
Wilcoxon القبلي والبعدي على مقياس الصلابة النفسية (الابعاد والدرجة الكلية) كمجوعتين مرتبطتين،

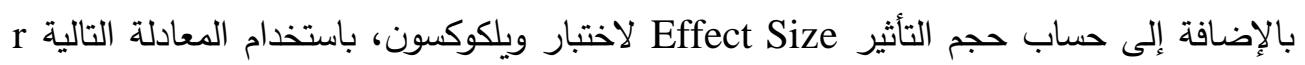
z/ n V= والبعدي من خلال الجدول التالي:

جدول (0)

قيم (Z) لدلالة الفروق بين متوسطي رتب درجات المجموعة التجريبية قبل وبعد تطبيق البرنامج

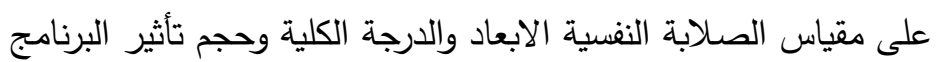

\begin{tabular}{|c|c|c|c|c|c|c|c|}
\hline حجم التأثير & مستوى الث & قيمة Z & مجر & مi & العدد & القياس & الابعاد \\
\hline \multirow[t]{2}{*}{ - , $\leqslant V$} & \multirow[t]{2}{*}{$\cdot, \ldots$} & \multirow[t]{2}{*}{ - r,ros } &.. &. & 10 & القبلي & \multirow[t]{2}{*}{ الالتزام } \\
\hline & & &.. & . & 10 & البعدي & \\
\hline \multirow[t]{2}{*}{$\cdot, \leqslant \wedge$} & \multirow[t]{2}{*}{$\cdot, \cdots 1$} & \multirow[t]{2}{*}{$-r, \varepsilon \| 1$} &.. &. & 10 & القبلي & \multirow[t]{2}{*}{ التحكم } \\
\hline & & &.. & . & 10 & البعدي & \\
\hline$\cdot, \varepsilon V$ & $\cdot, .$, & $-r$, rOS &.. & . & 10 & القبلي & التحدي \\
\hline
\end{tabular}




\begin{tabular}{|c|c|c|c|c|c|c|c|}
\hline & & & $\cdots$ & . & 10 & البعدي & \\
\hline \multirow[t]{2}{*}{$\cdot, \leqslant \wedge$} & \multirow[t]{2}{*}{$\cdot, \cdots}$, & \multirow[t]{2}{*}{$-r, \varepsilon \cdot \wedge$} & $\cdots$ & . & 10 & القبلي & \multirow[t]{2}{*}{ لارجة الكلية } \\
\hline & & & $\cdots$ & . & 10 & البعدي & \\
\hline
\end{tabular}

يتضح من جدول (0) وجود فروق ذات دلالة إحصائية بين متوسطي رتب درجات المجموعة التجريبية في القياسين القبلي والبعدي على مقياس الصلابة النفسية (الدرجة الكلية

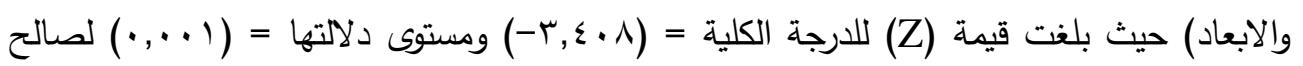
القياس البعدي كما يتضح أن حجم تأثير Effect Size البرنامج التدريبي في رفع مستوى الصلابة

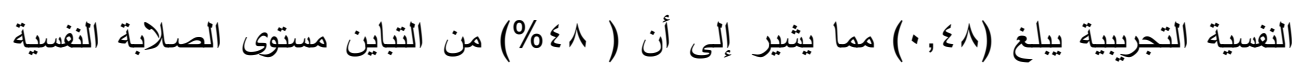

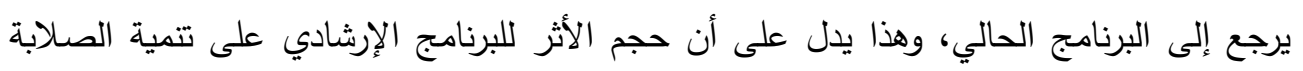

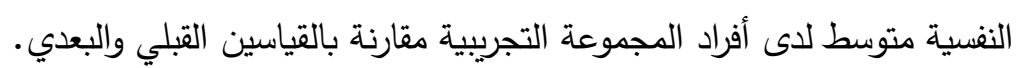
نتائج الفرض الرابع:

وينص على أنه: (توجد فروق ذات دلالة إحصائية بين متوسط رتب درجات افراد

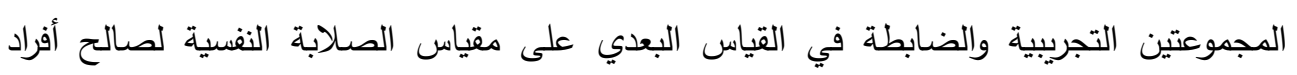
المجموعة التجريبية).

للتحقق من هذا الفرض تم استخدام اختبار مان ويتتي اللا بارامتري ( Mann-Whitney (Nonparametric

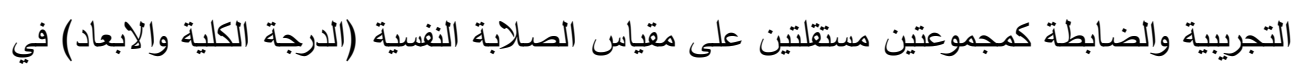
القياس البعدي، والجدول التالي يظهر دلالات الفروق بين بين المجموعتين التجريبية والضابطة في فيلين

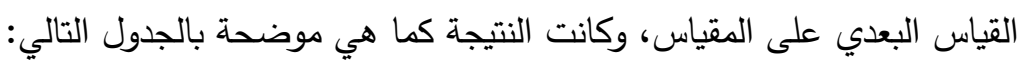

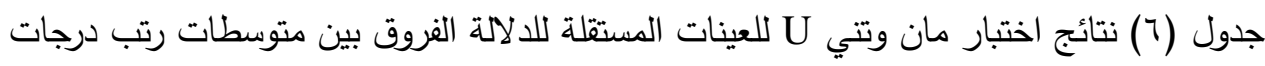

\begin{tabular}{|c|c|c|c|c|c|c|}
\hline مستوى الدلالة & $\overline{\mathrm{U}}$ & مجموع الرتب & متوسط الرتب & العدد & المجموعة & الابعاد \\
\hline \multirow[t]{2}{*}{,,$\ldots$} & \multirow[t]{2}{*}{$17,0 \ldots$} & rYA,O. & $r_{1, q .}$ & 10 & تجرببية & \multirow[t]{2}{*}{ الالتزام } \\
\hline & & 1r4,0. & 9,1 . & 10 & ضابطة & \\
\hline \multirow[t]{2}{*}{$\cdot, \ldots$} & \multirow[t]{2}{*}{$1,, \ldots$} & . & Tr, & 10 & تجربيية & \multirow[t]{2}{*}{ التحكم } \\
\hline & & r & $\Lambda, T \vee$ & 10 & ضابطة & \\
\hline \multirow[t]{2}{*}{$\cdot, \ldots$} & \multirow[t]{2}{*}{$0,0 \ldots$} & . & אד, זr & 10 & تجربيية & \multirow[t]{2}{*}{ التحدي } \\
\hline & & $1 r_{0,0}$. & $\Lambda, r v$ & 10 & ضابطة & \\
\hline$\cdot, \ldots$ & $\cdot, \cdots$ & $r \leqslant 0, \ldots$ & r & 10 & تجرببية & الدرجة الكلية \\
\hline
\end{tabular}




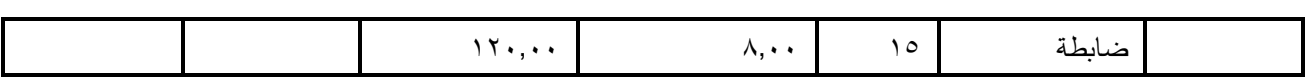

يتضح من جدول (7) وجود فروق دالة إحصائياً بين متوسطي رتب درجات المجموعتين

التجريبية والضابطة على مقياس الصلابة النفسية وابعاده في القياس البعدي لصالح المجموعة

$$
\text { التجريبية، عند مستوى دلالة ( ( . ., ). }
$$

من خلال النتائج السابقة بالجداول (0)، و (T) نجدها تتقق مع نتائج عدد من الدراسات

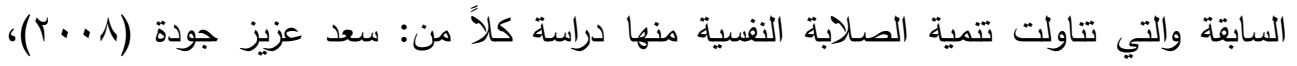

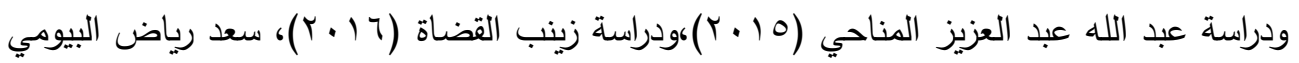
وعبد العال (T ا • r)، وتكشف هذه النتيجة بأن التحسن في مستوى الصلابة النفسية لدى العينة التجربية فقط وبقاء المجموعة الضابطة دون تغير ، لم يكن عائداً إلى الصدفة أو إلى عوامل أخرى، وإنما يعود إلى تطبيق البرنامج الإرشادي العقلاني الانفعالي، وذلك في ظل الظروف المحددة التي أجريت فيها الدراسة، وأن هذا التحسن ربما يعود إلى استخدام عدة أساليب وعوامل فعالة، في أثناء جلسات البرنامج الارشادي، أدت للوصول لهذه النتيجة منها التدريب على اكتساب مجموعة من الخصائص الإيجابية للثخصية، والتي ربما أكسبتهم خبرة معرفية ووقائية مكنتهم من مواجهة الأفكار والمشاعر السلبية ذات العلاقة بمستوى الصلابة النفسية مما كان لله أثر إيجابي في رفع مستوى الصلابة النفيية للمجموعة التجريبية، لذلك فإن الثخص الذي يتحمل الإحباط ولدية استبصار وفاعلية ذاتيه ومتفائل، ولديه تقدير عال للذات وضبط ذاتي ويتمتع بالثقة بالنفس والتعبير الحر عن الرأي والثعور بالمسئولية إزاء نتائج الاحداث التي تواجهه، وهذا يتماشى مع أهداف العلاج العقلاني الانفعالي الذي يؤكد على الجانب العقلي التجريدي الذي يتطلب جهاً لم يكن عند افراد المجموعة سابقاً مما اضفى تمايزاً في مستوى الصلابة النفسية لدى أفراد المجموعة التجربية، وكذلك التركيز على الأفكار غير المنطقية وبلورة مفاهيم منطقية عقلانية قد ساهم في تشكيل قاعدة يرتكز عليها الطالب في كيفية التعامل مع الأحداث بمختلف اشكالها الضاغطة منها والعادية وهو ما لم يتوافر لدى أفراد المجموعة الضابطة أو التجرببية قبل تطبيق البرنامج. نتائج الفرض الخامس: وينص على أنه (لا توجد فروق ذات دلالة إحصائية بين متوسط رتب درجات أفراد المجموعة التجربية في القياسين البعدي والتتبعي على مقياس الأفكار اللاعقلانية). للتحقق من هذا الفرض تم استخدام اختبار ويلكوكسون لإشارات الرتب Wilcoxon اللابارامتري لحساب دلالة الفروق بين متوسطي رتب درجات افراد المجموعة التجربيية في القياسين 
البعدي والتتبعي على مقياس الأفكار اللاعقلانية كمجوعتين مرتبطتين، وتتضح دلالة الفروق بين

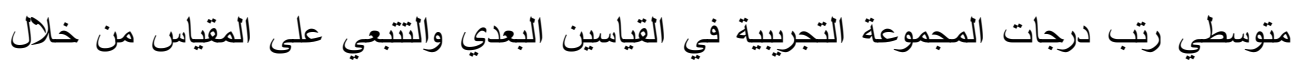

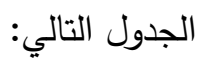

جدول (V) قيم (Z) لدلالة الفروق بين متوسطي رتب درجات المجموعة التجريبية للتطبيقين البعدي والتتبعي على مقياس الأفكار اللاعقلانية.

\begin{tabular}{|c|c|c|c|c|c|c|}
\hline الدستلاي & قيمة Z & مجموع الرتب & متوسط & العدد & القياس & المقياس \\
\hline \multirow[t]{2}{*}{$\cdot, \cdots 1$} & \multirow[t]{2}{*}{-r,r.r } & $\varepsilon, \cdots$ & $r,$. & 10 & البعدي & \multirow[t]{2}{*}{ الأفكار اللاعقلانية } \\
\hline & & $117, \ldots$ & $\Lambda, 9 Y$ & 10 & التتبعي & \\
\hline
\end{tabular}

يتضح من جدول V) وجود فروق ذات دلالة إحصائية بين متوسطي رتب درجات

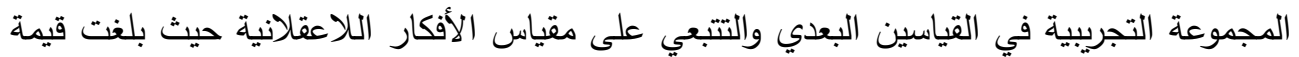

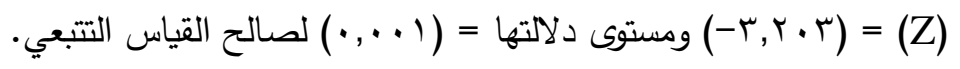
نتائج الفرض السادس:

ينص على أنه (لا توجد فـروق ذات دلالــة إحصـائية بـين متوسـط رتب درجـات أفراد

المجموعة التجريبية في القياسين البعدي والتتبعي على مقياس الصلابة النفسية).

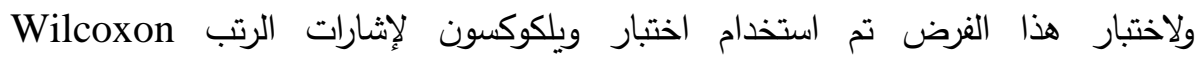
اللابارامتري لحساب دلالة الفروق بين متوسطي رتب درجات افراد المجموعة التجريبية في القياسين البعدي والتتبعي على مقياس الصلابة النفسية (الدرجة الكلية والابعاد) كمجموعتين مرتبطنين، وتتضح دلالة الفروق بين متوسطي رتب درجات المجموعة التجريبية في القياسين البعدي والتتبعي على المقياس من خلال الجدول التالي: جدول (^) قيم (Z) لدلالة الفروق بين متوسطي رتب درجات المجموعة التجريبية للتطبيقين البعدي والتتبعي على مقياس الصلابة النفسية الابعاد والدرجة الكلية.

\begin{tabular}{|c|c|c|c|c|c|c|}
\hline مستوى الدلالة & قيمة Z & مجموع الرتب & متوسط الرتب & العدد & القياس & الابعاد \\
\hline \multirow[t]{2}{*}{$\cdot, \ldots 7$} & \multirow[t]{2}{*}{$-r, V r V$} & $\Lambda \varepsilon, \ldots$ & $v, T \varepsilon$ & 10 & البعدي & \multirow[t]{2}{*}{ الالتزام } \\
\hline & & $v, \ldots$ & $r, 0$. & 10 & التتبعي & \\
\hline \multirow[t]{2}{*}{. Tro } & \multirow[t]{2}{*}{$-\cdot, \varepsilon \wedge 9$} & $11,0$. & $\varepsilon, 7 \pi$ & 10 & البعدي & \multirow[t]{2}{*}{ التحكم } \\
\hline & & r, 0. & $0, r$. & 10 & التتبعي & \\
\hline \multirow[t]{2}{*}{., .11} & \multirow[t]{2}{*}{$-r, 000$} & $v 1, \ldots$ & $v, 1$. & 10 & البعدي & \multirow[t]{2}{*}{ التحدي } \\
\hline & & $v, \ldots$ & $r, 0$. & 10 & التتبعي & \\
\hline., $.0 \mathrm{~V}$ & $-1,9.1$ & $9 r, \ldots$ & $\lambda, \leqslant 0$ & 10 & البعدي & الدرجة الكلية \\
\hline
\end{tabular}




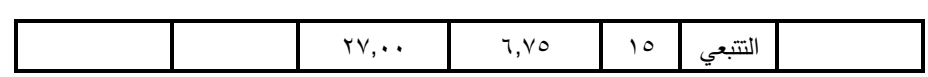

يتضح من جدول (^) عدم وجود فروق ذات دلالة إحصائية بين متوسطي رتب درجات المجموعة التجريبية في القياسين البعدي والتتبعي لمقياس الصلابة النفسية وذلك في الدرجة الكلية للمقياس ودرجة البعد الثاني. بينما توجد فروق ذات دلالة إحصائية للبعد الأول عند مستوى (.ا. (.)، والبعد الثالث

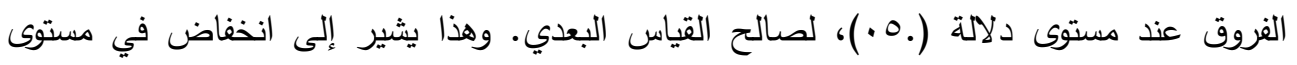
الصلابة النفسية على هذين البعدين فقط.

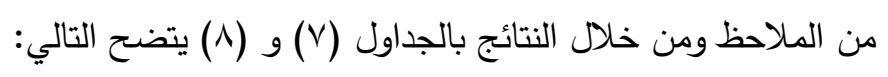

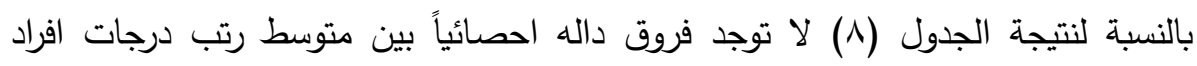
المجموعة التجريبية في القياسين البعدي والتتبعي على مقياس الصلابة النفسية (الدرجة الكلية والبعد

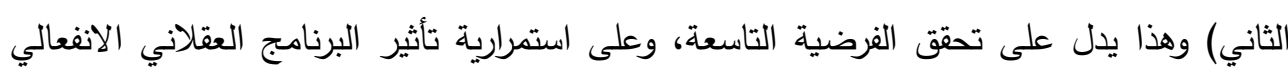

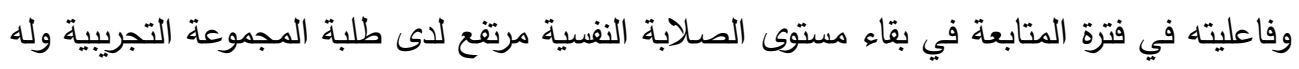

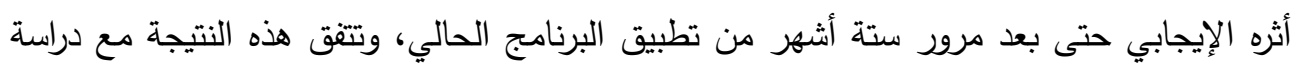

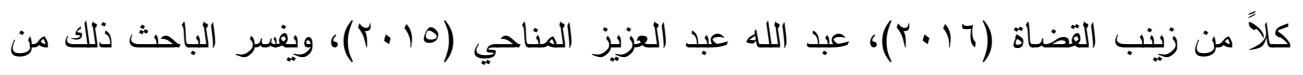
خلال محتوى البرنامج وما يشمل من علاقة إرشادية وطيدة بين الباحث وافراد المجموعة التجريبية

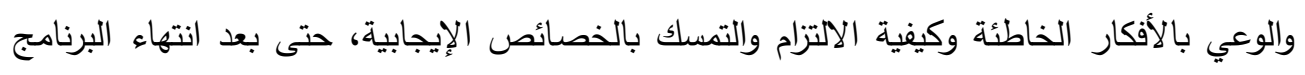

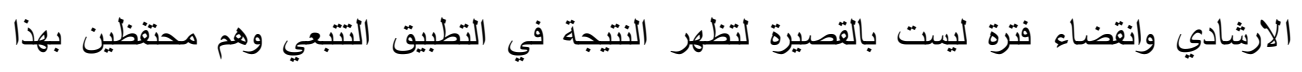

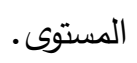
بينما كانت هناك فروق ذات دلالة إحصائية بين القياسين البعدي والتتبعي للمجموعة

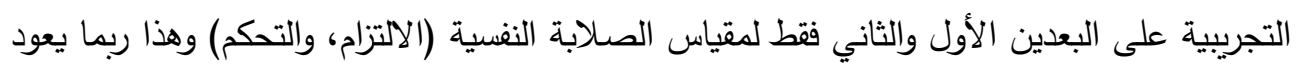
لأسباب منها: - بالنسبة لبعد الالتزام ظهرت فروق لصالح القبلي أي انخفاض الدرجات على هذا البعد وذلك لأن

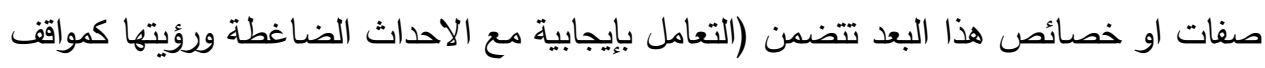
عادية، والإقبال على الحياة وأداء واجباته بطريقة هادفة، والمشاركة الاجتماعية الفعالة وإدراك

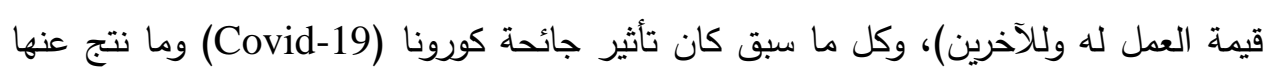

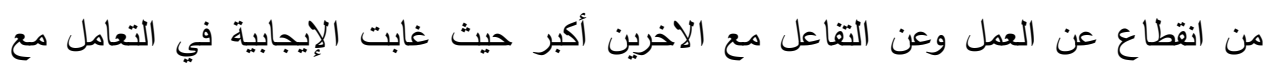

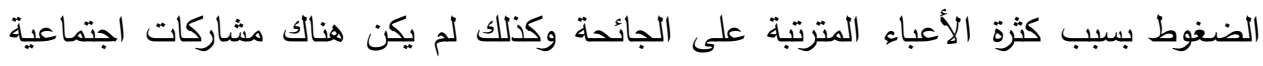


بسبب الحجر المنزلي وعدم الاختلاط مما قد يكون ساهم بشكل سلبي في درجات الالتزام في القياس التتبعي.

-وبالنسبة للبعد الثاني (التحكم) ظهرت فروق أي انخفاض في درجات التحكم فلو نظرنا إلى خصائص هذا البعد نجدها وهو (اعتقاد الطالب بإمكانية تحكمه فيما يلقاه من احداث ضاغطة من فن فئن

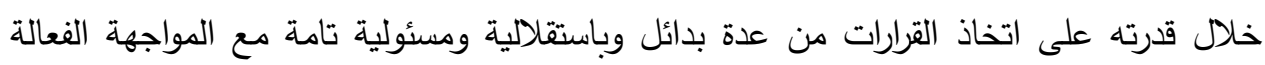

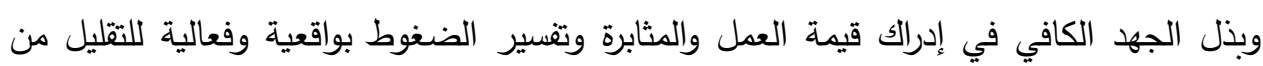

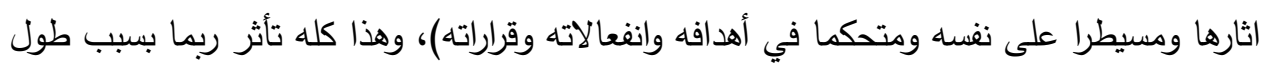
الفترة الزمنية بين التطبيقين وبسبب ظروف العزل والحجر المنزلي الذي جعل الطالب يفقد السيطرة

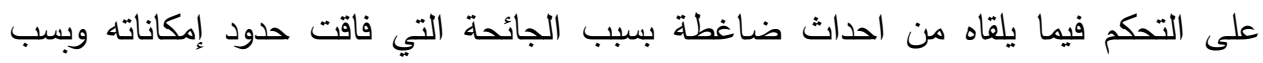
بطبيعة المرحلة التي يمر بها وهي تعتبر مرحلة ازمة حقيقية وحتى بدون ضغوط الجائحة وعدم وجود عمل أصلا لكي يدرك قيمته في ذلك الوقت الفاصل بين التطبيقين (البعدي والتتبعي).

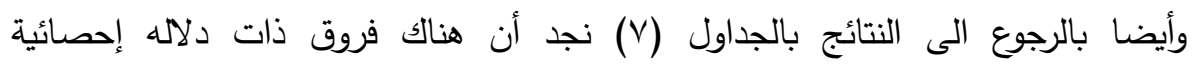
وبمستويات مختلفة بين القياسين البعدي والتتبعي للمجموعة التجريبية على مقياس الأفكار

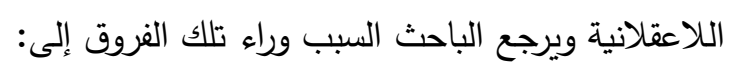
ا-طول الفترة الفاصلة بين التطبيقين البعدي والتتبعي حيث وصلت إلبى إلى ستة أشهر وذلك لعدم القدرة على الوصول للطلبة في تلك الفترة بالتحديد بسبب جائحة كورنا (Covid-19) وما لفيا ترتب عليها من ترتيات احترازية اتخذت من قبل الجهات المسئولة من أغلاق جزئي ثم كلي لوني

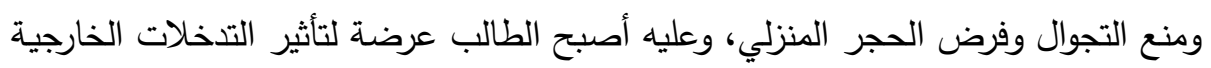

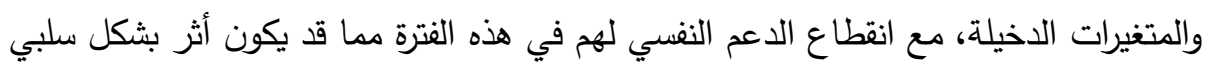

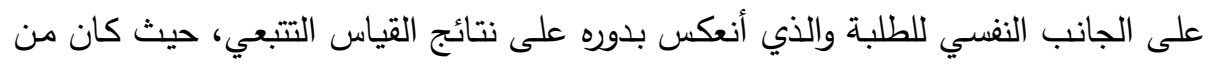

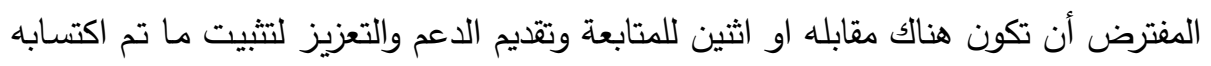
في اثثاء جلسات البرنامج الارشادي التي تم الوصول اليها، وقد طالت الفترة بين القياسين

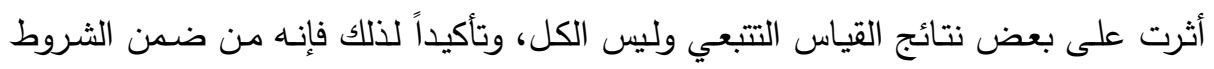

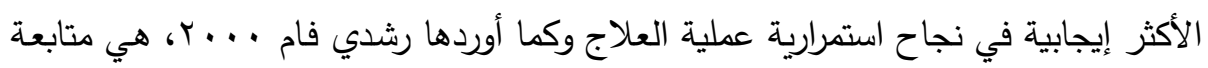

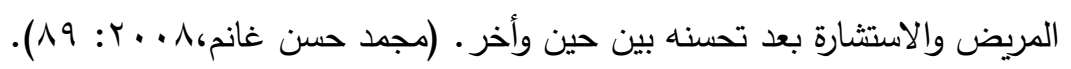

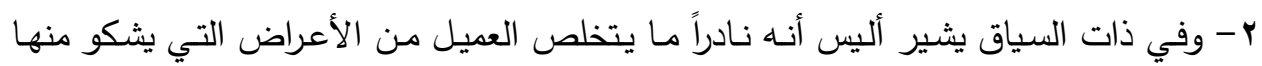

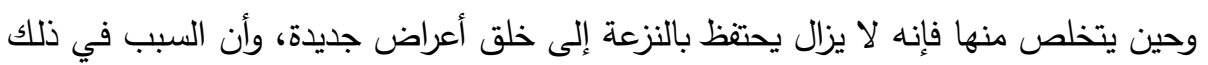


ليس لان الفرد نشأ على أفكار لا عقلانية ولكن لأنه أيضا يعيد غرس هذه اللاعقلانيات في

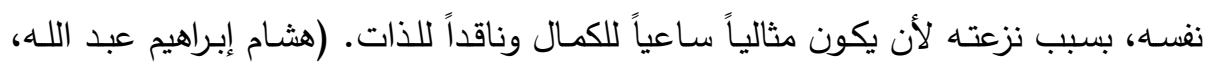

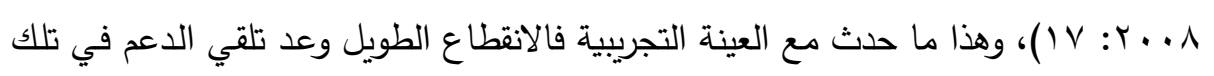
الفترة ربما أثر إلى حد ما وبشكل سلبي على نتائج القياس التتبعي.

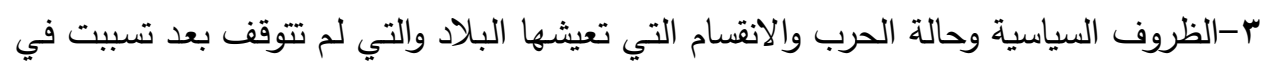

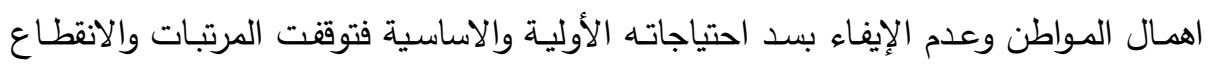

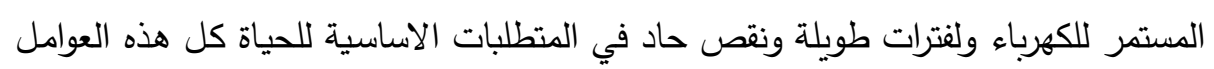

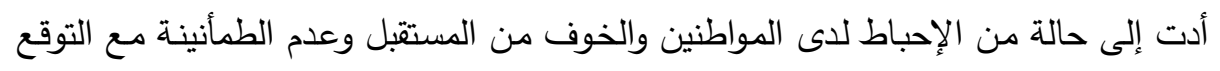
الدائم للتهديد، كل هذا ربما أثر بشكل سلبي على درجة الطلاب في التطبيق التتبعي مما زاد

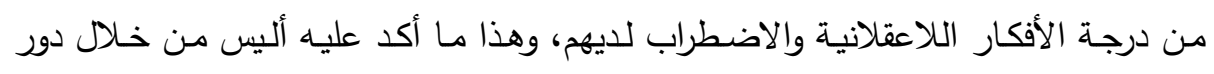

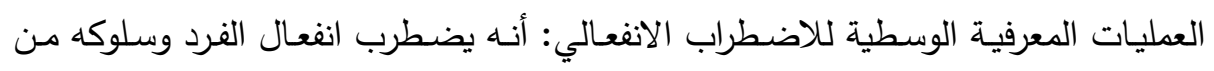
خلال انخفاض درجة تحمل الفرد للإحباط، وأيضا من خلال توقع الفرد الدائم للتهديد. (محمد الفعال

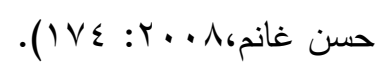

ع -يثير أليس أن العدائية وعدم الارتياح هما الأساس في الفعل غير العقلاني. (هشام إبراهيم

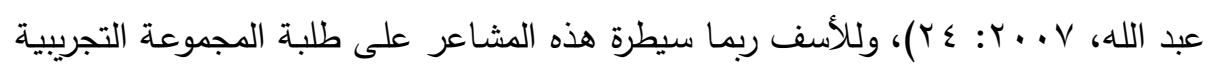

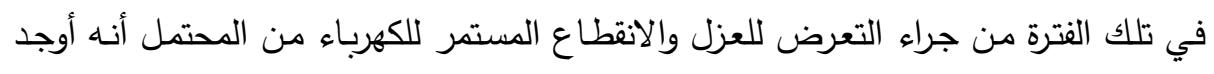

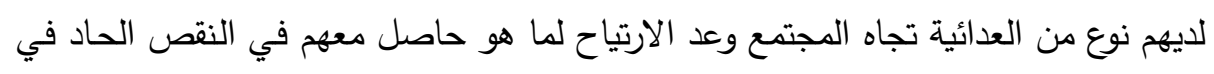
الخدمات والاحتياجات المعيشية وعدم الخروج من المنزل كل ذلك ربها كان لـان لـه أثر سلبي

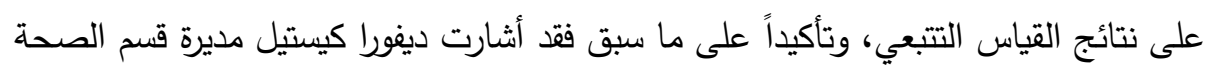

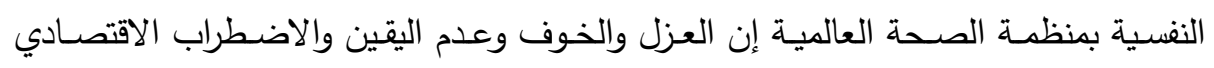

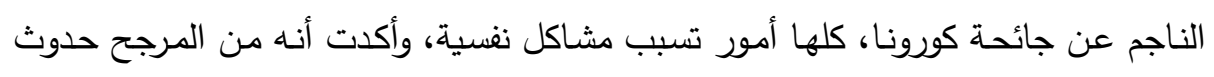
زيادة كبيرة في عدد الأشخاص الذين يعانون من الامراض النفسية ويجب على تلى الحكومات أن أن أنسات تضع هذه المسألة في صدارة استجاباتها للفيروس. - يثير أليس إلى أهمية الحديث الذاتي في عملية العلاج العقلاني ويقصد به الاقوال والأفكار التي

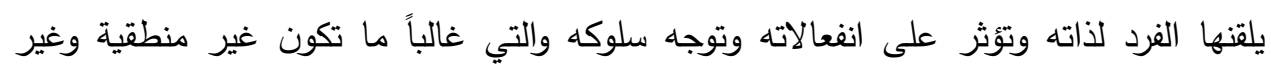

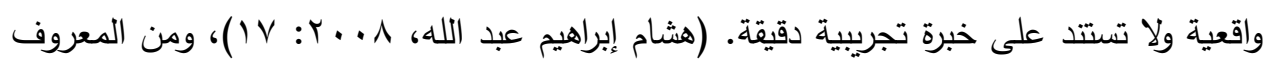
أن المراهقين تتنشر بينهم بثكل أكبر ما يعرف بأحلام اليقظة وربما وجودها مع الحديثة تئيث الذاتي 
السلبي وفي هذه الفترة الطويلة إلى حد ما بين التطبيقين (فترة الحجر المنزلي) بدون أصدقاء

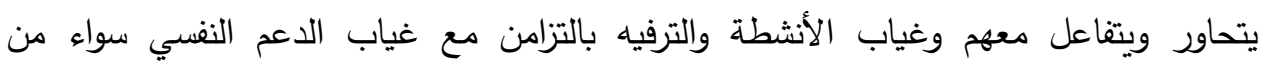

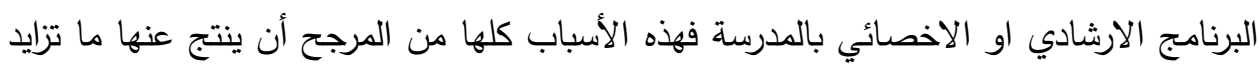

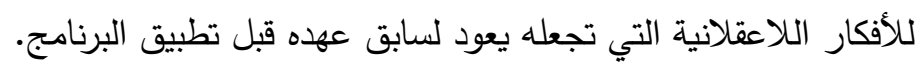
تعقيب على نتائج القياس اللاحق (التتبعي).

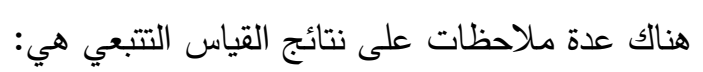
واجه الباحث صعوبة في الوصول للعينة التجريبية لإتمام القياس اللاحق (التتبعي) في

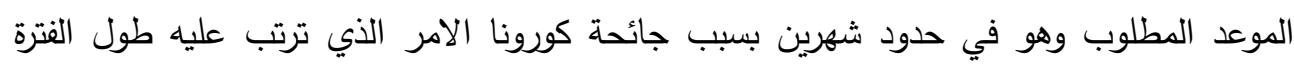

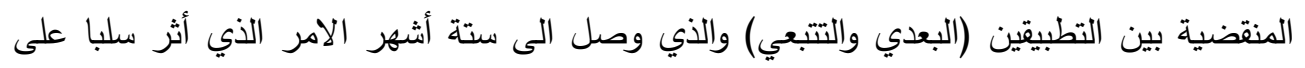

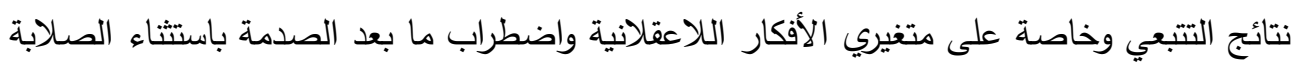
النفسية التي لم تتأثر كثيرا بطول الفترة • أن تغير النتائج بين القياسين البعدي والتتبعي شيء طبئيعي ومتوقع حدوثه بسبب طول الفترة

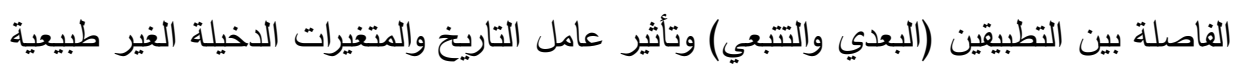
وغير متوقعة في تلك الفترة. • لأنهم اشخاص طبيعيين لا بد لهم أن يتأثروا بما يدور حولهم من قضايا ومشكلات، وإلا سوف يكونوا غير طبيعيين. • التغير حدث مع متغيري الأفكار اللاعقلانية فقط وهذا طبيعي لأنه متغير وقتي يتعير بتغير

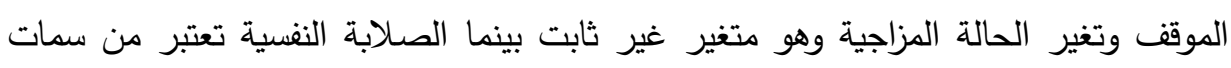
الثخصية (والسمات تتصف بالثبات النسبي)، لم تتأثر ولم يكن هنالك فروق دالة بئم بين الثين القياسين. • توصيات الدراسة:

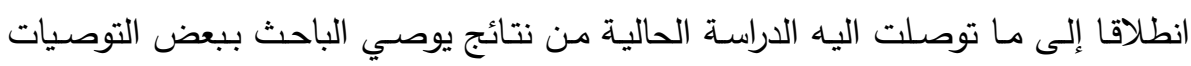

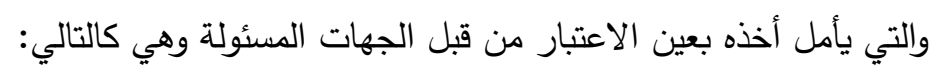
تفعيل دور المؤسسات التعليمية في الاهتمام بمفهوم الصـلابة النفسية كونـه مفهوما يساعد الاعدي

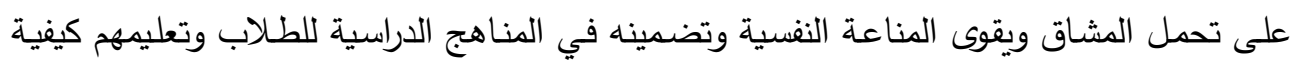
اكتسابه وخصوصاً لاى الأطفال والمراهقين. عمل بـرامج ارشـادية لتعزيـز الصـلابة النفسية لفئـات معينـة مـن المجتمـع مثل الأطفـال والمراهين الذين تعرضوا للعنف والاحداث الصادمة. 
عمل بـرامج ارشـادية للتوعيـة بخطورة التنكير اللاعقلانسي وكيفيـة التخلص منـه واكتسـاب

$$
\text { التفكير الجدلي المنطقي القائم على الاقناع والتجريب. }
$$

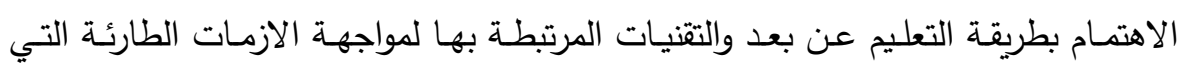

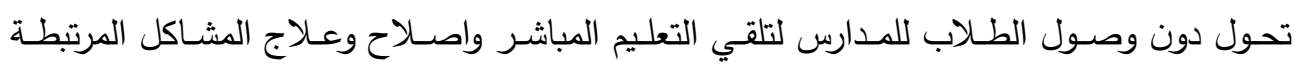
بتوصيل المعلومة عن بعد مثل الانترنت واتساع رقعة التغطية لكافة المناطق السكانية حتى يتم

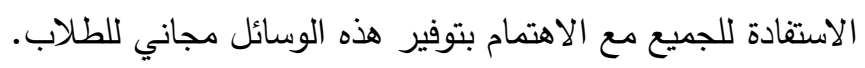

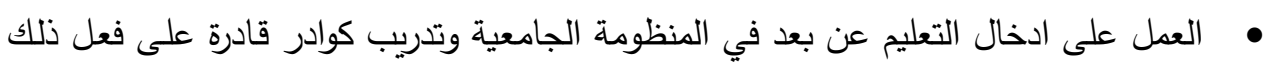

$$
\text { ليكون بديلاً للتعليم التقليدي في الحالات الحرجة. }
$$

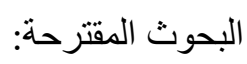

بناءً على ما توصلت إليه الدراسة الحالية من نتائج يقترح الباحث عدد من البحوث ذات

$$
\text { العلاقة بالدراسة ومتغيراتها وتتمثل في التالي: }
$$

• الارشـاد المدرسي ودوره في تتميـة الصـلابة النفسية لدى المـراهقين وأثرهـا على التحصيل

$$
\text { الدراسي. }
$$

$$
\text { • • الاتجاهات الوالدية ودورها في تتمية الصلابة النفسية لاى الأطفال }
$$

فعالية برنامج علاجي معرفي سلوكي قائم على المساندة الاجتماعية وتوكيد الذات في تتمية الإنية

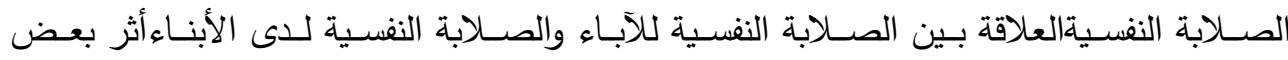
المتغيرات الديموغرافية في تتمية الصلابة النفسية وخفض القلق لدى المراهقين.

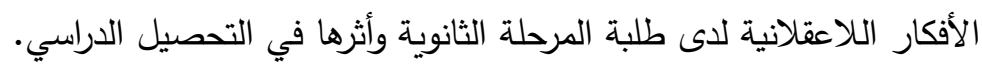

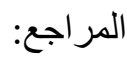

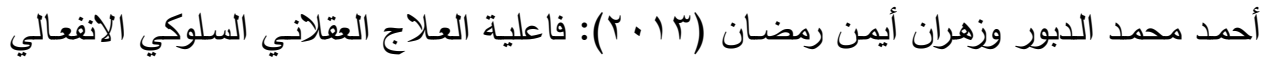
لتحسين جودة الحياة لعينة من الأطفال ذوي صعوبات التعلم، مجلة التربية الخاصة - مركز

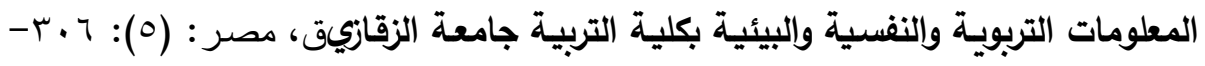

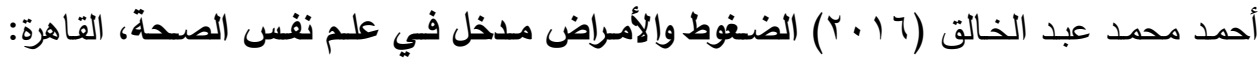
مكتبة الأنجلو المصرية 


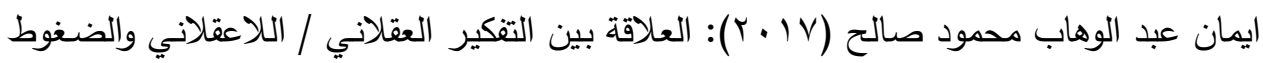

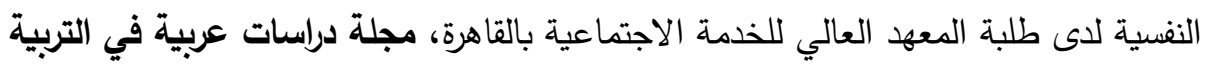

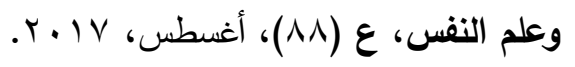

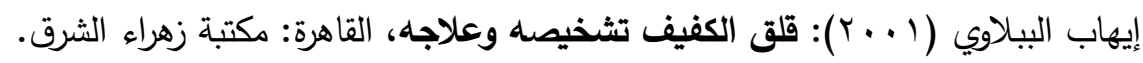

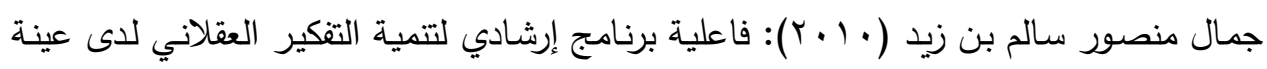
من الطلاب الجامعيين وأثره على بعض المتغيرات النفسية، رسـالة دكتوراه، كلية البنات، جامعة عين شمس.

راشد مانع العجمي، رياض العاسمي، حمد العجمي (10 ـ ب): الثعور بالأمن النفسي وعلاقته

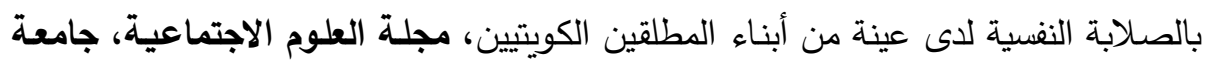

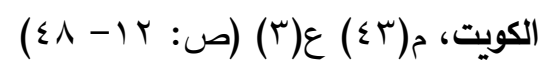

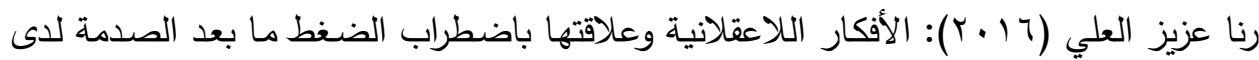

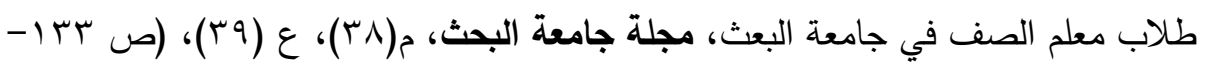

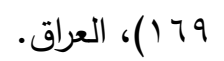

رياض نايل العاسمي (10 ـ ب): العلاج العقلانـي الانفعالي السلوكي بين النظريـة والممارسـة، عمان: دار الإعصار العلمي للنشر والتوزيع.

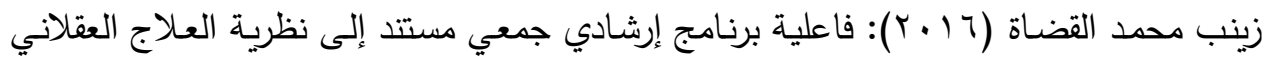
الانفعالي السلوكي في تتمية مستوى الصلابة النفسية لاى عينـة من الايتام في قرى الأطفال العالمية (SOS) رسالة ماجستير، كلية الدراسات العليا، جامعة مؤتة، الأردن.

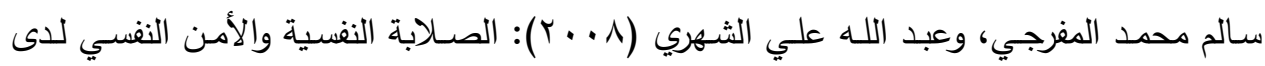
عينة من طلاب وطالبات جامعة أم القرى بمكة المكرمة، مجلة علم النفس المعاصر والعلوم الإنسانية، جامعة المنيا، م (9 (1) ) ع (أكتوبر ).

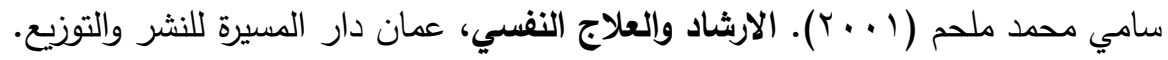

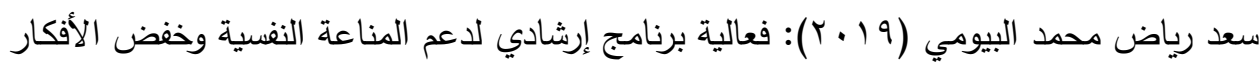

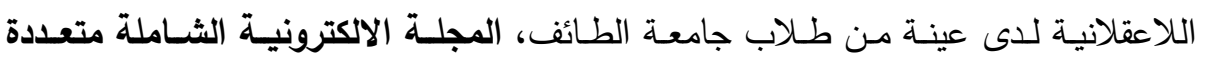

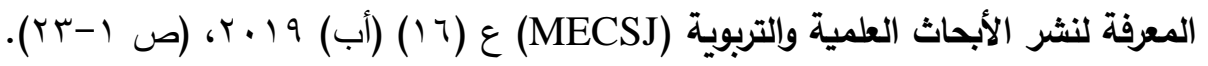


سعد رياض محمد البيومي، صبري محمد إسماعيل عبد العال (7 ( r): فاعلية برنامج إرشادي لتحسين الصلابة النفسية وكسر الحواجز النفسية لدى طلاب الجامعة، مجلة العلوم التربويـة،

$$
\text { مصر: }
$$

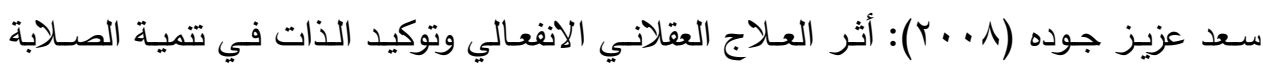
النفسية، رسالة دكتوراه، كلية التربية، الجامعة المستتصرية، العراق.

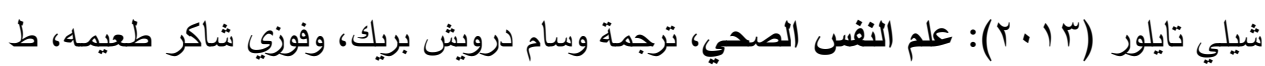

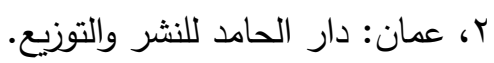
صفاء الأعسر (•(1): الصمود من منظور علم النفس الإيجابي، المجلة المصرية للدراسـات

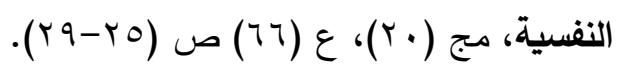

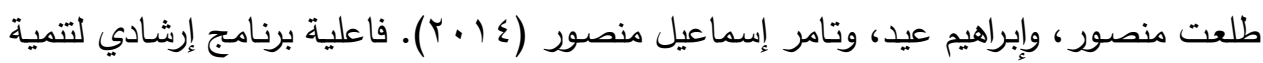

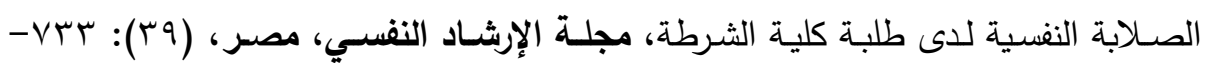

$$
\text { . VVA }
$$

طلعت منصور ، وإبراهيم عيد، وتامر إسماعيل منصور ( ( + ؟). فاعلية برنامج إرشادي لتتمية

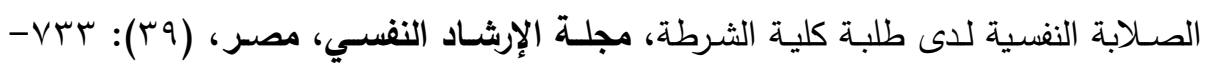

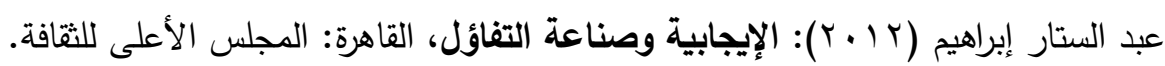

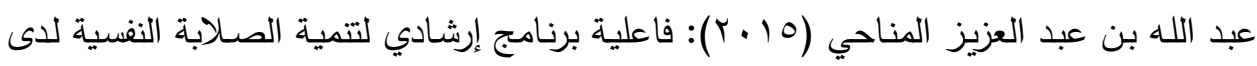

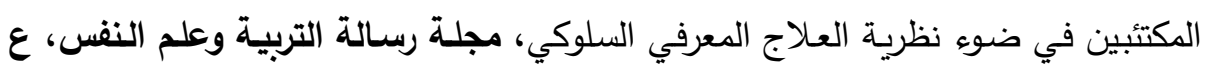

$$
(\mid \vee 7-101)(\leqslant \wedge)
$$

عبد الله بن عبد العزيز المناحي (Y V V V): فاعلية برنامج إرشادي نفسي في تعديل الأفكار غير

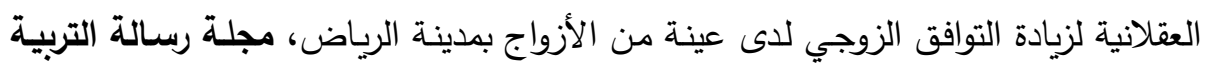

$$
\text { وعلم النفس، ع (OV)، السعودية. }
$$

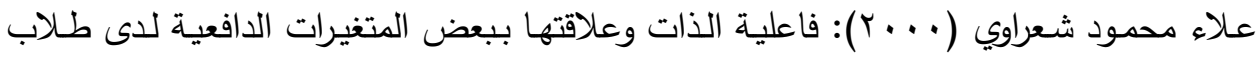

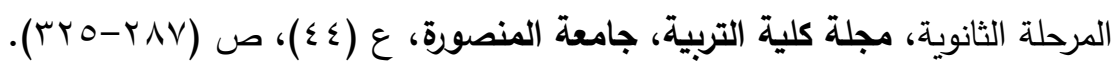

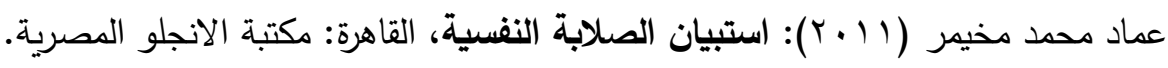
فراس ياسين القعدان (Y V V V): الأفكار العقلانية واللاعقلانية وفق نظريـة ألبرت أليس وعلاقتها

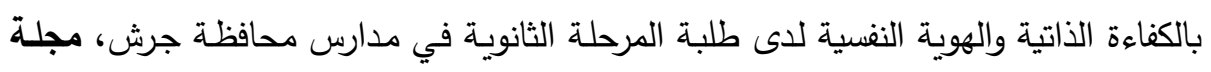




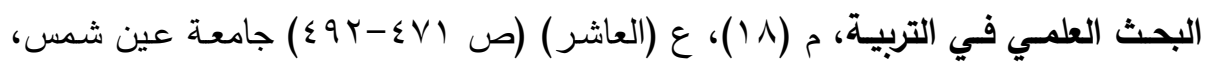
كلية البنات للآداب والعلوم التربوية. فيوليت وفام فؤاد، وجورجيت عجايبي وشند، سميرة محمد إبراهيم (r ( ب): فاعلية برنامج إرشادي

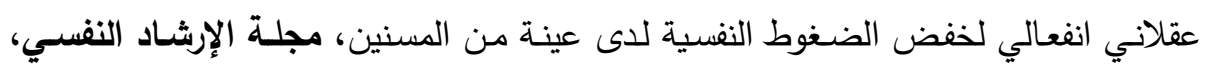

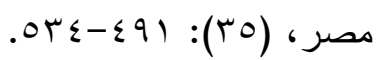

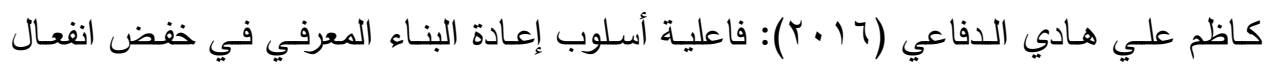

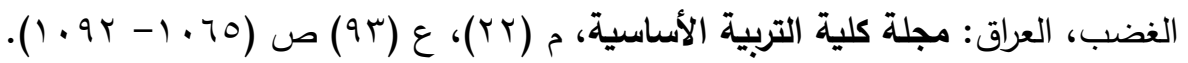
محمد أبراهيم عيد (0 ب). مقدمة في الإرشاد النفسي، القاهرة: مكتبة الاتجلو المصرية.

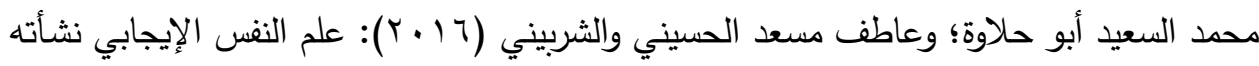
وتطوره ونماذج من قضاياه، القاهرة: عالم الكتب. محمد حسن غانم (^ . . ץ). العلاج النفسي، القاهرة: مكتبة مدبولي. معتز سيد عبد الله، محمد السيد عبد الرحمن (99V (1)): إعداد مقياس " الأفكار " اللاعقلانية

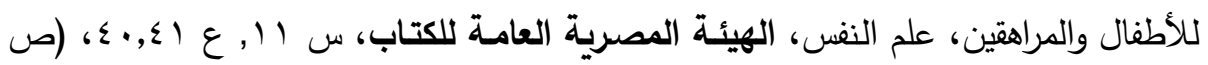
.( $(1 \leq 1-1) \leqslant$

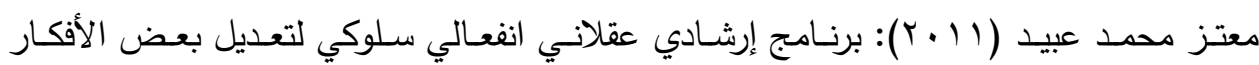

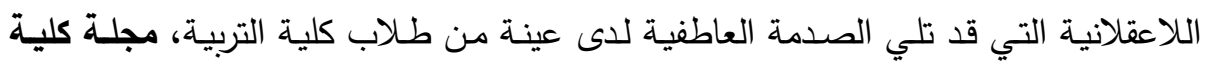

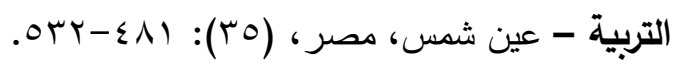
مكي، لطيف غازي مكي، وبراء محمد حسن (11 + (1): صلابة الثخصية وعلاقتها بتقدير الذات

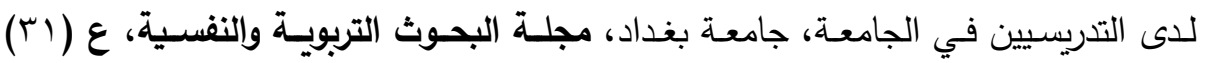

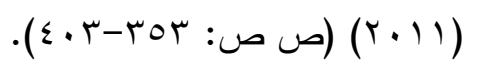

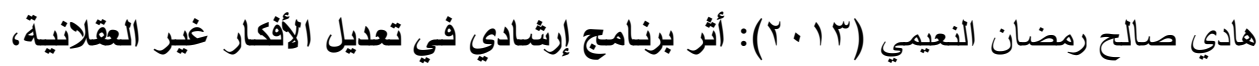
كلية التربية، جامعة كركوك، العراق: مطبعة نارا بخا. هالة خير سناري إسماعيل (Y V V Y): المرونة النفسية وعلاقتها باليقظة العقلية لدى طلاب كلية

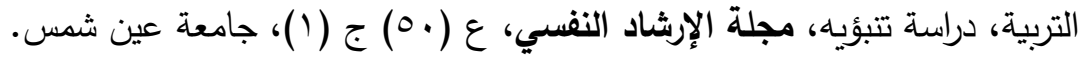

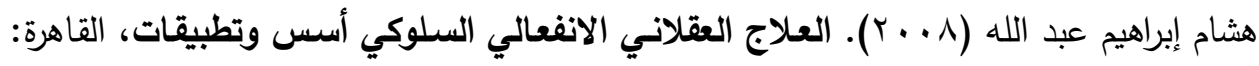

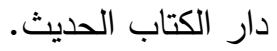




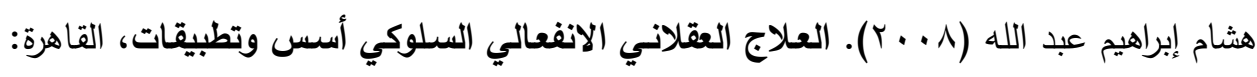

دار الكتاب الحديث.

Bigalke, Kathryn Lynch. (2015). Coping, hardiness, and parental stress in parents of children diagnosed with cancer. Doctor of Philosophy. University of Southern Mississippi. USA.

Keyem M. D. \& Pidgeon, A. M. (2013). An Investigation of the Relationship between Resilience, Mindfulness, and Academic SelfEfficacy. Open Journal of Social Sciences, 1 (6), 1-4.

Kobasa, S. C. (1979). Stressful life events, personality, and health: an inquiry into hardiness. Journal of personality and social psychology, 37(1), 1.

Ryff, c. (1989). Happiness is everything or is it? Exploration on the Meaning of Psychology well- Being, Journal of Personality and Social Psychology, 57 (3), 1069-1081.

Whatley, Jennifer Anne. (2015). Exploring relationships among selfperceived irrational and rational beliefs, goal orientations, and human behaviors in school professionals. Doctor of Education. The University of West Florida. USA.

Wiebe, D. J. (1991). Hardiness and stress moderation: A test of proposed mechanisms. Journal of personality and social psychology, 60(1), pp, 89-99

Zhang, Li- Fang \& Wong, Yau- Ho. (2011). Hardiness and thinking styles: Implications for higher education, Journal of Cognitive Education and Psychology, 10 (3), 294-307. 